\title{
ECOLOGIA TRÓFICA DE Astyanax paranae (OSTEICHTHYES, CHARACIDAE) EM CÓRREGOS DA BACIA DO RIO PASSA- CINCO, ESTADO DE SÃO PAULO
}

\author{
ANDERSON FERREIRA
}

Dissertação apresentada à escola superior de Agricultura “Luiz de Queiroz”, Universidade de São Paulo, para obtenção do título de Mestre em Ecologia de Agroecossistemas.

\section{PIRACICABA}

Estado de São Paulo - Brasil

Maio - 2004 


\title{
ECOLOGIA TRÓFICA DE Astyanax paranae (OSTEICHTHYES, CHARACIDAE) EM CÓRREGOS DA BACIA DO RIO PASSA- CINCO, ESTADO DE SÃO PAULO
}

\author{
ANDERSON FERREIRA \\ Biólogo \\ Orientador: Prof. Dr. JOSÉ EURICO POSSEBON CYRINO
}

Dissertação apresentada à escola superior de Agricultura "Luiz de Queiroz", Universidade de São Paulo, para obtenção do título de Mestre em Ecologia de Agroecossistemas.

\section{PIRACICABA}

Estado de São Paulo - Brasil

Maio - 2004 


\section{Dados Internacionais de Catalogação na Publicação (CIP) DIVISÃO DE BIBLIOTECA E DOCUMENTAÇÃO - ESALQ/USP}

\section{Ferreira, Anderson}

Ecologia trófica de Astyanax paranae (Osteichthyes, Characidae) em córregos da bacia do Rio Passa-Cinco, Estado de São Paulo / Anderson Ferreira. - - Piracicaba, 2004.

56 p. : il.

Dissertação (mestrado) - - Escola Superior de Agricultura Luiz de Queiroz, 2004.

Bibliografia.

1. Bacia hidrográfica 2. Biologia animal 3. Dieta animal 4. Ecologia animal 5. Lambari 6. Rio Passa-Cinco I. Título

CDD 639.375

\section{"Permitida a cópia total ou parcial deste documento, desde que citada a fonte - O autor"}




\section{Dedico}

A Deus,

Em especial à minha mãe Cleide, que sempre me incentivou e me deu forças para continuar

Aos meus irmãos, pela eterna ajuda e por acreditarem em mim 


\section{AGRADECIMENTOS}

Ao Prof. Dr. José Eurico Possebon Cyrino pela orientação, confiança e apoio em todos os momentos.

Ao doutorando e amigo Pedro Gerhard pelos ensinamentos, coletas de campo, identificação dos espécimes e que sem sua ajuda este trabalho não teria sido realizado.

Ao Prof. Dr. Luciano Verdade pela infra-estrutura e por me aceitar como agregado.

À Profa. Dra. Norma Segatti Hahn pela amizade, auxílio nas análises deste trabalho e por ceder o Laboratório de Alimentação de Peixes.

Ao Laboratório de Ecologia Animal e ao Setor de Piscicultura pelos espaços concedidos para realização deste trabalho.

Ao Dr. Flávio Lima (MUZUSP) pela identificação dos exemplares estudados.

À Dr. Lilian Casatti pela leitura e sugestões.

À Flipper, amiga e irmã, que me mostra a tantos anos como a amizade verdadeira é importante na vida. Muito obrigado por estar do meu lado nos momentos de alegrias e tristezas.

Á Raquel, que tive a felicidade de conhecer e tornar-se seu amigo. Muito obrigado pela nossa amizade que será eterna.

Ao Elio por toda ajuda na realização deste trabalho, pelo exemplo de profissionalismo e principalmente por ser meu melhor amigo em Pira.

Ao Henrique pela amizade e exemplo de dedicação. 
Á Rosa pela nossa eterna amizade e pela ajuda nas análises laboratoriais.

Á Elaine, que me ajudou e incentivou a fazer meu projeto e acreditou no meu potencial.

À Valdirene e Fernando pela ajuda nas análises dos dados.

À Rubiane pelo amor e compreensão.

À Pisgui pela amizade e apoio.

A todos os amigos e companheiros da Vila Estudantil pelos bom momentos juntos. Em especial: Milena Ramires e Júlio.

A todos os companheiros do Laboratório de Ecologia Animal, especialmente à Cláudia B. Campos, Kátia Ferraz e André Villaça.

Ao estagiários, Tma, Sapão, Prisioneiro, Hadija, Ixalá, e Pastor pela ajuda em campo, no laboratório e por todas as beronhices realizadas.

Ao técnicos Sérgio e Júnior pela atenção e companheirismo.

Á CAPES pela concessão da bolsa de mestrado.

A todos que forma indireta contribuíram para a realização deste trabalho. 


\section{SUMÁRIO}

Página

LISTA DE FIGURAS .................................................................................... viii

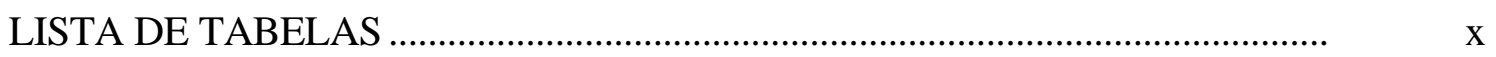

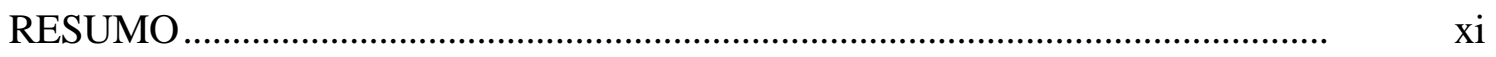

SUMMARY ...............................................................................................

1 INTRODUÇÃO

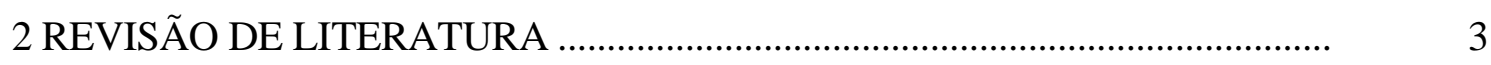

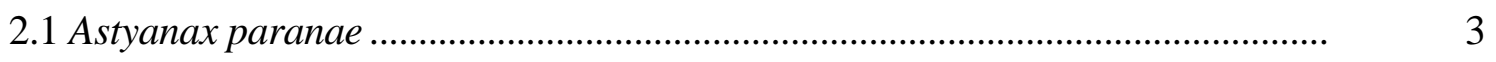

2.2 Dieta de peixes em riachos brasileiros.............................................................. 5

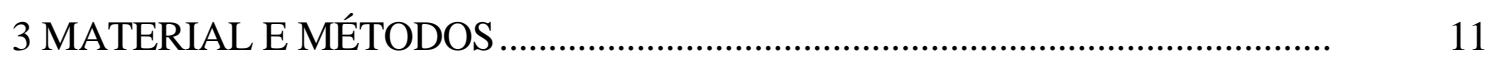

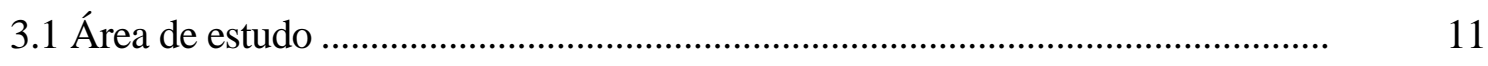

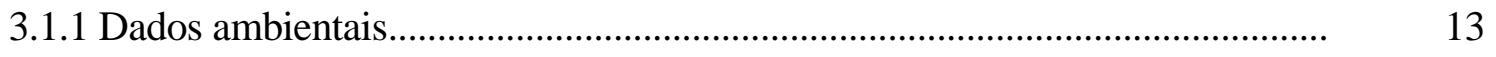

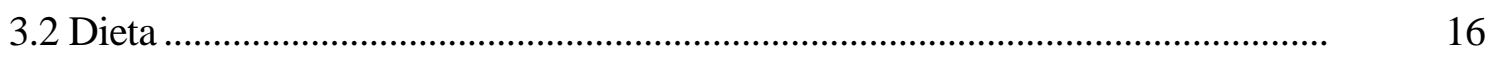

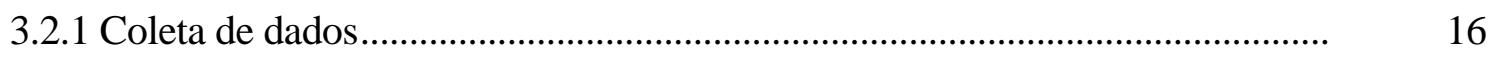

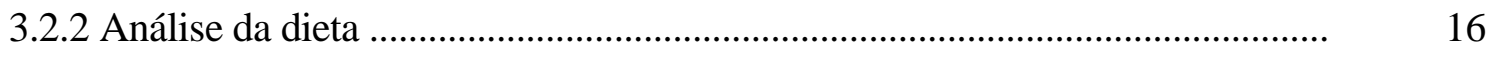

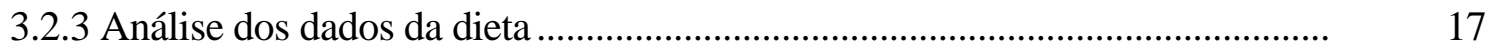


3.3.1 Coleta das amostras

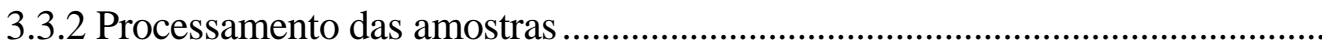

3.3.3 Análise dos dados

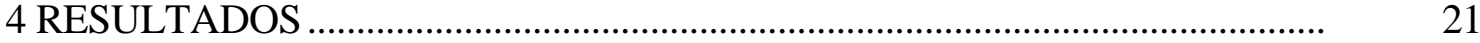

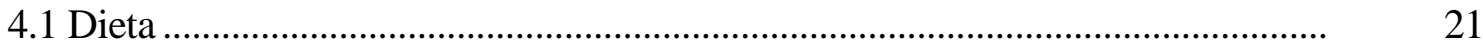

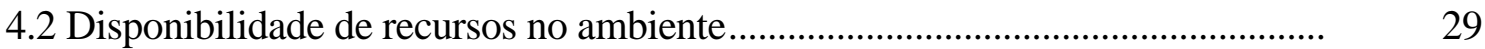

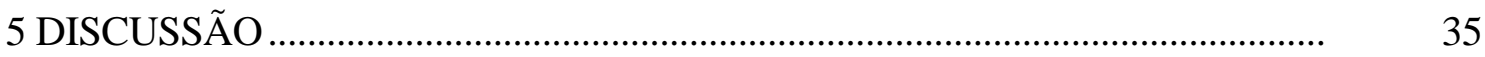

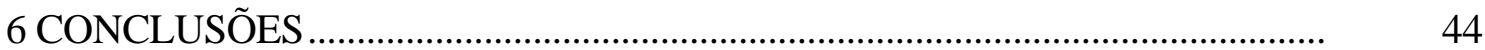

REFERÊNCIAS BIBLIOGRÁFICAS ................................................................ 


\section{LISTA DE FIGURAS}

Página

1 Astyanax paranae, coletado no Córrego Paredão - SP

2 Localização da bacia do rio Passa-Cinco no Estado de São Paulo, indicando os pontos de coleta ..................................................................

3 Porcentagem de freqüência de ocorrência e volumétrica dos recursos alimentares utilizados por $A$. paranae nos córregos a) Paredão e b) Jibóia. $1=$ outros, $2=$ inseto aquático, 3= vegetal terrestre, 4= algas, 5= inseto terrestre, $6=$ invertebrado terrestre e $7=$ detrito/sedimento.

4 Freqüência de ocorrência e volumétrica dos recursos alimentares utilizados por A. paranae nos córregos a) Cantagalo e b) Anzol. $1=$ outros, $2=$ insetos aquáticos, 3 = vegetal terrestre, 4 = algas, 5 = insetos terrestres, $6=$ invertebrados terrestres e $7=$ detrito/sedimento

5 Freqüência de ocorrência e volumétrica dos recursos alimentares utilizados por A. paranae nos córregos a) Areião e b) Vereador. $1=$ outros, $2=$ insetos aquáticos, $3=$ vegetal terrestre, $4=$ algas, $5=$ insetos terrestres, $6=$ invertebrados terrestres e $7=$ detrito/sedimento .......................................

6 Freqüência volumétrica (V\%) da origem dos itens alimentares na dieta de A. paranae nos diferentes córregos da bacia do rio Passa-Cinco, SP ........... 
7 Amplitude do nicho trófico de Astyanax paranae em seis córregos da bacia do rio Passa-Cinco, SP................................................................................. 26

8 Atividade alimentar (GR\%) de A. paranae no período vespertino nos córregos da bacia do rio Passa-Cinco, SP...................................................... 27

9 Ordenação espacial (A) e dos recursos alimentares (B) utilizados por $A$. paranae nos diferentes córregos da bacia do rio Passa-Cinco, SP ................. 28

10 Dendograma de similaridade entre os córregos e as categorias alimentares utilizadas por A. paranae na bacia do rio Passa-Cinco, SP, obtido através dos escores da DCA.......................................................................................

11 Diversidade dos invertebrados $\left(H^{\prime}\right)$ de acordo com a origem nos córregos da bacia do rio Passa-Cinco, SP

12 Índice de Eletividade dos recursos ingeridos por A. paranae em relação aos disponíveis nos córregos amostrados da bacia do rio Passa-Cinco, SP .. 


\section{LISTA DE TABELAS}

Página

1 Características físico-químicas e bióticas amostrados no momento da coleta dos peixes nos córregos da bacia do rio Passa-Cinco .........................

2 Classificação dos substratos minerais por tamanho de partícula..................... 13

3 Porcentagem de uso do solo do corredor ripário dos córregos amostrados na bacia do rio Passa-Cinco ......................................................................... 14

4 Comprimento padrão médio e número de exemplares de $A$. paranae analisados nos córregos da bacia do rio Passa-Cinco, SP

5 Porcentagens de ocorrência $(\mathrm{O})$ e de volume $(\mathrm{V})$ dos itens alimentares consumidos por Astyanax paranae em seis córregos da bacia do rio PassaCinco, SP ( $\mathrm{n}=$ ninfa, $\mathrm{l}=$ larva, $\mathrm{p}=$ pupa, $\mathrm{a}=$ adulto)

6 Ocorrência (O) e porcentagem de ocorrência (\%) dos invertebrados de origem autóctone nos córregos da bacia do rio Passa-Cinco ( $\mathrm{n}=$ ninfa, $1=$ larva, $\mathrm{p}=$ pupa, $\mathrm{a}=$ adulto)

7 Ocorrência (O) e porcentagem de ocorrência (\%) dos invertebrados de origem alóctone nos córregos da bacia do rio Passa-Cinco ( $\mathrm{n}=\operatorname{ninfa}, 1=$ larva, $\mathrm{p}=$ pupa, $\mathrm{a}=$ adulto) 


\section{ECOLOGIA TRÓFICA DE Astyanax paranae (OSTEICHTHYES, CHARACIDAE) EM CÓRREGOS DA BACIA DO RIO PASSA- CINCO, ESTADO DE SÃO PAULO.}

Autor: ANDERSON FERREIRA

Orientador: Prof. Dr. JOSÉ EURICO POSSEBON CYRINO

\section{RESUMO}

Frente aos distúrbios que os ambientes aquáticos sofreram nas últimas décadas e os conseqüentes impactos causados sobre a ictiofauna, é cada vez mais relevante o entendimento da biologia e ecologia dos peixes nestes ecossistemas. O presente trabalho teve como objetivo relacionar a dieta do lambari Astyanax paranae em córregos de substrato e composição do corredor ripário distintos na bacia do rio Passa-Cinco (SP), verificando as diferenças existentes na alimentação da espécie, a origem dos itens alimentares, a disponibilidade de invertebrados e suas relações com a dieta da espécie. As coletas foram realizadas no período vespertino de fevereiro a abril de 2003. Para a captura dos peixes foram utilizados métodos combinados de pesca elétrica, rede de arrasto manual e peneiras. Para as amostragens dos invertebrados utilizou-se um amostrador tipo Surber, bandejas de retenção, redes de mão e deriva. Os conteúdos gástricos foram analisados através dos métodos de frequência de ocorrência e volumétrico. A espécie apresentou um amplo espectro alimentar. A categoria alimentar dominante foi representada por insetos 
terrestres, com maiores ocorrências para Formicidae (recursos alóctones). No Córrego Cantagalo, que apresenta a zona ripária constituída por pastagens, os insetos aquáticos foram a categoria alimentar mais representativa (recursos autóctones). Para medir a amplitude de nicho alimentar aplicou-se a medida de Levins e os maiores valores foram registrados nos córregos Paredão e Jibóia, indicando que A. paranae utilizou mais amplamente os recursos disponíveis nestes ambientes de mata ripária melhor preservada. A atividade alimentar deste lambari foi avaliada através do grau de repleção estomacal (GR). Os indivíduos analisados apresentaram conteúdos alimentares na maioria dos estômagos, confirmando seu período alimentar diurno. Para agrupar os locais de coleta com base na dieta de $A$. paranae, utilizou-se uma análise de correspondência e de agrupamento, que segregou os córregos onde a espécie consumiu mais insetos terrestres (córregos Paredão, Areião e Vereador), uma maior variedade de itens (Córrego Jibóia), algas (Córrego do Anzol) e insetos aquáticos (Córrego Cantagalo). A grande maioria dos invertebrados disponíveis nos riachos foram compostos por insetos em estágios imaturos e adultos, tanto de origem aquática quanto terrestre. Em todos os córregos amostrados, os invertebrados alóctones apresentaram maior diversidade e menor abundância em relação aos invertebrados autóctones, exceto no Córrego Vereador (zona ripária com mata alterada) onde a abundância foi maior. Para avaliar a seleção dos recursos por A. paranae utilizou-se o Índice de Eletividade de Ivlev. O recurso alóctone foi selecionado positivamente em todos os córregos pela espécie e apenas no Córrego Cantagalo houve consumo de itens autóctones na mesma proporção que a encontrada no ambiente. A espécie apresentou um hábito alimentar onívoro com tendência à insetivoria, sendo que a dieta foi influenciada pelas características geomórficas dos córregos e do corredor ripário. A presença da vegetação ripária foi importante para alimentação da espécie, demonstrada pelo maior consumo de recursos alóctones e também para a diversidade dos invertebrados. As condições de assoreamento não influenciaram na dieta devido a entrada dos recursos externos e, apesar da grande disponibilidade de recursos autóctones nos diversos córregos, A. paranae demonstrou preferência pelos itens alóctones. 


\title{
TROPHIC ECOLOGY OF Astyanax paranae (OSTEICHTHYES, CHARACIDAE) IN STREAMS OF THE PASSA-CINCO RIVER BASIN, STATE OF SÃO PAULO
}

\author{
Author: ANDERSON FERREIRA \\ Adviser: Prof. Dr. JOSÉ EURICO POSSEBON CYRINO
}

\section{SUMMARY}

Environmental disturbances of the last decades had major impact in fish fauna, turning the understanding of fish biology and ecology in aquatic ecosystems each time more relevant. This study analyses the diet of lambari Astyanax paranae in streams with different substrates and composition of the riparian corridor in the Passa-Cinco river basin (SP), regarding the relationship of local differences in species diet, origin of food items, and availability of invertebrates to the species diet. Fish were collected in the afternoon from February to April 2003, by either electrofishing or seining net. Surber sampler, forest litter trays half-filled with a soap solution, dip nets and drift nets were used for sampling invertebrates. Fish stomach contents were analyzed by the frequency of occurrence and volumetric methods. The species prsented a wide feeding spectrum. Terrestrial insects (mostly Formicidae) represented the most dominant feeding category. Aquatic insects were the most representative feeding category in the Cantagalo stream, which presented a riparian corridor covered with pasture. The Levins's measure was used to evaluate niche breadth. The higher values were obtained in the Paredão and 
Jibóia streams, ecosystems characterized by pristine forest in the riparian corridor, eliciting better use of available resources by A. paranae. The feeding activity of the lambari was evaluated by the degree of stomach repletion (GR). Most individuals presented alimentary items in their stomachs, confirming a diurnal feeding habit. The analysis of cluster and correspondence were used to group study sites based on A. paranae feeding. These analysis segregated streams where the species consumed more terrestrial insects (Paredão, Jibóia, and Vereador streams), larger variety of items (Jibóia streams), algae (Anzol stream) and aquatic insects (Cantagalo stream). Immature and adult insects were the most available invertebrates in the streams. Allochthonous invertebrates presented higher diversity and lower abundance in relation to the autochthonous invertebrates in all systems, except in the Vereador stream, which presented a riparian corridor covered by anthropogenic forest. The resource selection by A. paranae was evaluated by Ivlev's Electivity Index. Allochthonous resources were positively selected by the species in all streams but Cantagalo, where consumption of autochtonous and allochthonous resources were equal. The species presented an omnivorous feeding habit, tending to insectivorous. Feeding habits could be related both to geomorphic stream features and riparian corridor vegetation cover. The riparian vegetation was an important food source for the species, as demonstrated by the higher allochthonous resources consumption, and also by the invertebrates diversity. Streambed sand filling did not influenced species persistence, as it could rely on external resources input. A. paranae demonstrated preference by allochthonous food items besides the high availability of autochthonous resources. 


\section{INTRODUÇÃO}

Em todas as regiões do país tem sido constatado a diminuição na quantidade e qualidade da água nos ambientes aquáticos continentais, principalmente em microbacias onde o desmatamento indiscriminado e o uso de sistemas de cultivo inadequados, além da degradação ambiental, estão levando ao desaparecimento dos rios de cabeceira. Estas ações antrópicas, além de acarretarem problemas sócio-econômicos, geram impactos ambientais imensuráveis tanto para fauna quanto para a flora.

A integridade da vegetação na zona ripária é de suma importância para a sobrevivência dos organismos aquáticos, pois promove proteção estrutural do habitat, regulando o fluxo d'água, a formação de abrigos e de sombras, além do fornecimento de alimento direto (insetos terrestres, frutos e sementes) e indireto (matéria orgânica). Desta forma, as modificações artificiais ocorridas nestas áreas, podem alterar seu substrato, as estruturas geomórficas ,as propriedades físico-químicas da água e afetar a fauna dos riachos, atingindo diretamente à ictiofauna, no que diz respeito aos processos vitais como reprodução e alimentação das espécies.

Frente aos distúrbios que os ambientes aquáticos sofreram nas últimas décadas e

os consequentes impactos causados sobre a ictiofauna, é cada vez mais relevante o entendimento da biologia e ecologia dos peixes nestes ecossistemas. No entanto, a maior parte do conhecimento sobre ecologia trófica de peixes no Brasil se restringe a espécies de grande porte em rios e lagos, ou seja, as espécies de maior interesse comercial e alguns estudos sobre os impactos decorrentes da construção de hidrelétricas.

A maioria dos trabalhos em pequenos cursos d’água não estão relacionados com a vegetação associada ou com os diferentes graus de degradação destes ambientes. Neste sentido, o presente trabalho destaca-se por estudar a auto-ecologia de Astyanax paranae, 
uma espécie típica de cabeceira, através do estudo de sua dieta, visando ampliar o conhecimento das interações ecológicas entre peixes de riachos neotropicais, com as características ambientais que influenciam a oferta dos recursos alimentares. Por se tratar de uma espécie endêmica destes ambientes, o conhecimento sobre o hábito alimentar de A. paranae em ecossistemas alterados, traz importantes informações sobre sua adaptabilidade, bem como fornece relevante contribuição para planos de conservação e recuperação de áreas degradadas.

Este trabalho foi conduzido buscando verificar a seguinte hipótese: as características morfológicas dos córregos e do corredor ripário, influenciam na dieta do lambari A. paranae, através da oferta dos recursos alimentares. Assim, este estudo apresentou o objetivo geral de analisar a dieta de $A$. paranae em córregos da bacia do rio Passa-Cinco, e os objetivos específicos de verificar as diferenças na dieta de A. paranae nos diversos córregos estudados, determinar a origem dos itens alimentares consumidos pela espécie, caracterizar a disponibilidade de invertebrados nos diferentes córregos e relacionar a oferta de invertebrados com a dieta da espécie. 


\section{REVISÃO DE LITERATURA}

\subsection{Astyanax paranae}

A ictiofauna neotropical apresenta a maior diversidade e riqueza de peixes de água doce conhecida (Lowe-McConnell, 1999; Nakatani et al., 2001). Segundo Reis et al. (2003), atualmente existem mais de 4.000 espécies descritas e há estimativas de que possam existir cerca de 6.000 .

A ordem Characiformes é o grupo dominante entre os peixes de água doce da América do Sul, sendo a família Characidae a maior e mais complexa desta ordem (Fowler, 1948; Godoy, 1975; Nelson, 1984; Britski et al.,1999). A forma dos corpos dos representantes dessa família e os biótopos que habitam são extremamente variados, englobando um número de espécies maior que o de todas as famílias dessa ordem (Godoy, 1975; Nakatani et al., 2001).

Um dos grupos mais comuns em riachos são os Tetragonopterinae, sendo a subfamília de Characidae com o maior número de gêneros e espécies (Fowler, 1948; Godoy, 1975; Britski et al.,1999; Buckup, 1999), possuindo parte de sua sistemática mal definida e representando um aglomerado polifilético (Menezes, 1992; Britski et al.,1999; Buckup, 1999). A maioria das espécies pertencentes a este grupo é onívora e apresenta hábitos de forrageamento muito ativos (Britski et al., 1988). Ocorrem desde a fronteira dos Estados Unidos com o México até a Argentina e são popularmente conhecidas no Brasil como lambaris ou piabas (Britski, 1972).

Os tetragonopteríneos mais freqüentes nos riachos do sudeste do Brasil são as espécies dos gêneros Astyanax, Bryconamericus, Deuterodon, Hollandichthys, Moenkhausia, Piabina, Hemigrammus e Hyphessobrycon (Godoy, 1975; Buckup, 1999). As mais recentes classificações estão reunindo as espécies da subfamília 
Tetragonopterinae em um grupo provisoriamente denominado como "genera incertae sedis”, devido a diversos problemas nomenclaturais e filogenéticos (Buckup, 2003; Lima et al., 2003).

O gênero Astyanax foi inicialmente proposto por Baird \& Girard, 1854 e a primeira revisão mais completa deste gênero, realizada por Eigenmann entre 1921 e 1927, validou 74 espécies e subespécies. Posteriormente, Gèry (1977) enumerou uma lista de 62 espécies e subespécies em águas doce do Brasil. A revisão mais recente, realizada por Lima et al. (2003), cita 86 espécies e as poucas sub-espécies existentes foram elevadas a espécies.

Astyanax scabripinnis Jenyns, 1842, popularmente conhecido como lambari-dorabo-vermelho, é uma espécie de pequeno porte que normalmente habita pequenos corpos d’água (Gomes \& Azevedo, 1960; Britski, 1972, Castro \& Casatti, 1997; Medri et al., 2002). Diferenciações morfológicas dentro desta espécie foram notadas primeiramente por Eigenmann no início do século passado, quando sugeriu a existência de várias subespécies (Mizoguchi \& Martins-Santos, 1998). Posteriormente, Fowler (1948) listou seis subespécies: A. scabripinnis scabripinnis (Jenyns, 1842), A. scabripinnis intermedius (Eigenmann, 1908), A. scabripinnis laticeps (Cope, 1894), A. scabripinnis longirostris (Steindachner, 1907), A. scabripinnis intermedius (Eigenmann, 1908) e A. scabripinnis paranae (Eigenmann, 1927).

Estudando sete populações de A. scabripinnis nas bacias dos rios Paranapanema, São Francisco e Tietê, Moreira-Filho \& Bertollo (1991) demonstraram a grande diversidade, tanto morfológica quanto cariotípica, desta espécie. Assim, estes autores utilizaram o termo “complexo scabripinnis” para designar estas populações e relacionam a diversidade destes peixes ao isolamento em microbacias nos grandes sistemas hidrográficos. Mizoguchi \& Martins-Santos (1998) estudaram quatro populações deste “complexo” em três bacias hidrográficas diferentes e encontraram diferenças cariotípicas e morfológicas em todas as populações. Devido aos diversos problemas de identificação e porque apresenta uma ampla distribuição geográfica e diversidade cariotípica, esta espécie se tornou alvo de diversos estudos citogenéticos (Morelli et al., 1983; MoreiraFilho \& Bertollo, 1991; Alves \& Martins-Santos, 2002). 
As populações de peixes podem responder às diferentes condições ambientais recorrendo a mecanismos de adaptação, como plasticidade fenotípica ou seleção genética, mostrando flexibilidade nas taxas de crescimento, idade da primeira maturação, dentre outros fatores biológicos (Wootton, 1992). O estudo de peixes de cabeceiras de rios é interessante de um ponto de vista evolutivo devido à ocorrência de um número pequeno de indivíduos isolados geograficamente (Maistro et al., 2000), como é o caso desta espécie de lambari.

Diversos trabalhos sobre o complexo A. scabripinnis são encontrados na literatura, abordando a biologia e aspectos reprodutivos (Barbieri, 1993b; Sá, 2000; Fragoso, 2000; Roque et al., 2003 e Veregue \& Orsi, 2003), parasitismo (Gioia \& Cordeiro, 1986; Gioia et al., 1988; Cordeiro \& Gioia, 1990), estrutura populacional e crescimento (Barbieri, 1993a), número de processos rastelares (Jablonski et al., 2000), estrutura e funcionamento de hemoglobinas (Landini et al., 2002), alimentação e nutrição (Barbieri, 1992; Tavares et al., 1994; Castro \& Casatti, 1997; Uieda et al., 1997; Roque et al., 2003).

Segundo Garutti \& Britski (2000), A. scabripinnis paranae, descrita por Eigenmann (1914), é considerada uma espécie comum na bacia do alto rio Paraná, formando numerosas populações isoladas entre si em cabeceiras de rios. Os lambaris estudados neste trabalho foram classificados de acordo com a chave para espécies de Astyanax do alto rio Paraná (Garutti \& Britski, 2000), portanto identificados como A. scabripinnis paranae. Com a tendência de elevar as subespécies ao status de espécie, $A$. scabripinnis paranae passou a ser classificada taxonomicamente como Astyanax paranae Eigenmann, 1914 (Figura 1) (Buckup, 2003; Lima et al., 2003).

\subsection{Dieta de peixes em riachos brasileiros}

Os estudos sobre a alimentação de peixes em riachos no Brasil indicam que as informações existentes sobre o assunto são bastante fragmentadas e escassas (Esteves \& Aranha, 1999). Na região amazônica, Soares (1979) analisou a dieta de 20 espécies de peixes coletadas em quatro trechos do igarapé do Porto, Aripuanã (MT), no início do

período chuvoso. As análises dos conteúdos estomacais indicaram abundância e 
diversidade de alimentos, principalmente os de origem alóctone. De maneira geral, seus resultados confirmam que em igarapés de águas claras da região tropical, as espécies ocupam todo o espaço disponível, devido à disponibilidade de alimentos, às adaptações morfológicas e aos hábitos que caracterizam os diversos grupos.

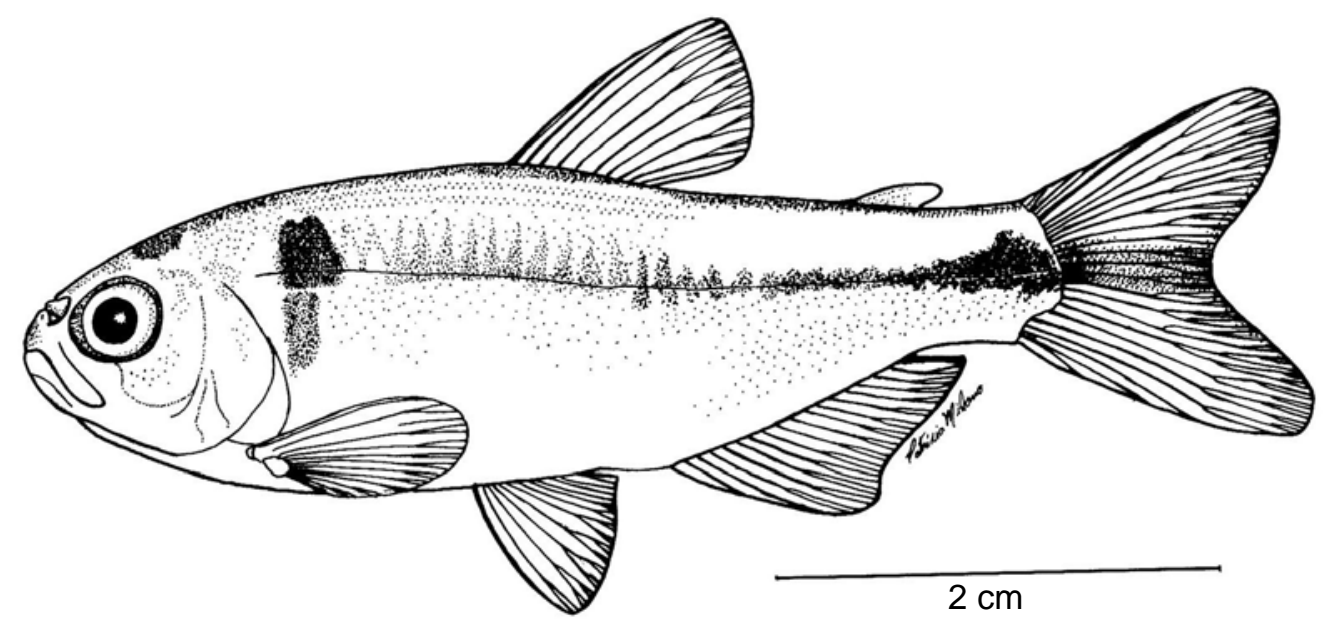

Figura 1 - Astyanax paranae, coletado no Córrego Paredão - SP

Henderson \& Walker (1986) em um estudo da comunidade de "litter" (serrapilheira ou aglomerado de folhas) do riacho Tarumãzinho na Amazônia Central, observaram que aproximadamente 20 espécies de pequenos peixes possuíam hábito bentônico, explorando os invertebrados que estavam associados ao "litter”. Costa (1987) estudou os hábitos alimentares de 17 espécies em dois trechos do rio Mato Grosso (RJ) e analisou a dieta das espécies espacial e sazonalmente (seca e cheia). Os principais itens alimentares consumidos foram de origem aquática, não ocorrendo espécies que se alimentaram somente de itens terrestres. A maioria das espécies não apresentaram diferenças sazonais na alimentação e apenas algumas consumiram diferentes itens nos distintos trechos

Uieda et al. (1987) analisaram a dieta dos peixes encontrados em dois trechos do rio Claro (MG) e construíram uma rede alimentar para estes ambientes. Encontraram uma maior complexidade na rede da comunidade do trecho à jusante, devido à maior 
diversidade e abundância de peixes, decorrentes de um ambiente mais amplo e com maior diversidade de habitats. Com relação à dieta, os itens alóctones (vegetais e insetos terrestres) e autóctones (principalmente larvas de dípteros e tricópteros) representaram as principais fontes alimentares.

Teixeira (1989) avaliou aspectos tróficos de 25 espécies de peixes presentes num trecho do arroio Bom Jardim (RS). A maioria das espécies alimentaram-se de insetos e microcrustáceos sendo que, neste trabalho, os insetos não foram separados de acordo com a origem. Apesar da maioria das espécies se alimentarem dos mesmos itens, não houve sobreposição alimentar, pois segundo o autor, isto pode estar relacionado com a habilidade que cada espécie tem para capturar os insetos que estão disponíveis, ou seja, aqueles que passam todo o seu ciclo de vida na água ou aqueles que caem na água trazidos pelo vento.

Sabino \& Castro (1990) estudaram a alimentação, o período de atividade e a distribuição de 8 espécies do rio Indaiá, Estado de São Paulo. A análise da dieta mostrou que a principal categoria alimentar consumida foi representada por insetos, tanto terrestres quanto aquáticos, enquanto que as algas filamentosas corresponderam à segunda categoria mais freqüente. Os autores ainda ressaltaram a grande dependência da comunidade de peixes deste riacho em relação aos itens alimentares provenientes da floresta, pressupondo que alterações naquela mata poderão modificar substancialmente a estrutura da comunidade de peixes de um rio de pequeno porte como o Indaiá, mesmo levando-se em conta a plasticidade alimentar de suas espécies.

Lobón-Cerviá et al. (1993) analisaram a dieta de Crenicichla lepidota em dois riachos nos pampas gaúchos e observaram mudanças nas táticas alimentares da espécie entre os períodos de inverno, onde a dieta foi constituída principalmente por efemerópteros e verão, onde os principais itens foram zooplâncton e diversas espécies bentônicas. Soares-Porto (1994) determinou a composição da dieta e definiu os horários de maior atividade alimentar de Pimelodella lateristriga no rio Ubatiba (RJ). A autora definiu a espécie como bentófoga e onívora, com tendência à carnivoria e verificou que o ritmo de atividade alimentar foi predominantemente crepuscular a noturno, com picos eventuais durante o dia. 
Silva (1993) estudou a alimentação e distribuição espacial de 29 espécies de peixes do igarapé do Candirú (AM), onde a maioria das espécies apresentaram preferências por microhabitats específicos. A autora atribuiu a alimentação dos peixes como sendo a possível causa dessa preferência.

Buck \& Sazima (1995) analisaram a distribuição, atividade e alimentação de quatro loricarídeos em um trecho aberto e outro dentro da mata de galeria do ribeirão da Serra (SP). Segundo os autores, as quatro espécies se alimentaram dos mesmos recursos (algas), mas diferiram quanto ao período de atividade e ao uso de habitat. Além disto, observaram que na área aberta ocorreu maior densidade de loricarídeos forrageando do que no interior da mata, devido a maior produtividade primária e a maior taxa de remoção de sedimentos sobre as algas.

Uieda et al. (1997) estudaram a dieta de peixes do Córrego Itaúna (SP) e constataram o maior consumo foi de itens autóctones, principalmente formas jovens de insetos aquáticos. Desta forma, a maioria das espécies foi classificada como insetívoras, seguidas por insetívoras-herbívoras e perifitívoras. Castro \& Casatti (1997) analisaram os conteúdos estomacais da ictiofauna de um afluente do rio Pardo (SP), indicando que a maioria das espécies possuíam o hábito insetívoro. Apenas algumas espécies foram classificadas como onívoras com tendência à insetivoria e poucas herbívoras e insetívoras-piscívoras. Dentre os itens alimentares, 61\% eram autóctones (principalmente algas e larvas aquáticas de insetos) e $31 \%$ alóctones (principalmente artrópodos terrestres).

O trabalho realizado por Luiz et al. (1998), determinou a dieta e a estrutura trófica das assembléias de peixes nos riachos Água Sumida e Arigó (PR). Os principais recursos alimentares utilizados no primeiro riacho foram peixes e detritos orgânicos, enquanto que no segundo foram plantas e detritos orgânicos, sendo os detritívoros e os onívoros as guildas mais abundantes nestas assembléias.

Casatti \& Castro (1998) estudaram a ictiofauna de um trecho de corredeiras do curso superior do rio São Francisco (MG), analisando os períodos de atividade, distribuição espacial e a biologia alimentar das espécies residentes no trecho estudado. 
Os recursos autóctones (insetos aquáticos e algas perifíticas) foram os itens alimentares mais importantes para a comunidade.

Em um riacho em Bonito (MS), Sabino \& Sazima (1999) relatam a associação alimentar entre a piraputanga, Brycon microlepis, e o macaco prego, Cebus apella. Este estudo apontou que os primatas comem frutos na vegetação do riacho e, durante sua alimentação derrubam ramos, folhas e frutos na água. Desta forma, os peixes são atraídos por esta atividade e consomem os frutos, seguindo o bando de macacos durante seu forrageamento ao longo do riacho.

Esteves \& Lobón-Cerviá (2001) estudando a composição e a estrutura trófica da comunidade de peixes num riacho de terceira ordem de mata Atlântica no Estado de São Paulo, detectaram a maior importância dos recursos alóctones e, entre as guildas tróficas determinadas para a comunidade, o grupo mais abundante foi o insetívoro, seguido por detritívoros, bentívoros, onívoros, herbívoros e piscívoros.

Vilella et al. (2002) analisaram a dieta de seis espécies de Astyanax no rio Maquié (RS) e consideram todas as espécies onívoras, sendo os insetos e restos de vegetais superiores os itens alimentares mais importantes. Os autores ainda sugerem que as espécies possam estar atuando como dispersoras de sementes, principalmente de macrófitas.

A disponibilidade de invertebrados aquáticos para peixes bentófagos foi verificada por Russo et al. (2002) através da análise dos conteúdos estomacais de diversas espécies de Trichomycterus nos córregos Marcão e Barra Grande, na bacia do rio Iguaçu, estado do Paraná. A análise da dieta revela grande diversidade de invertebrados bentônicos, principalmente famílias de efemerópteros, dípteros e tricópteros. Não houve diferenças na dieta entre os riachos, época do ano e os tamanhos dos indivíduos.

Casatti (2002) investigou a estrutura trófica de uma comunidade de peixes em três trechos do Córrego São Carlos (SP). A análise dos conteúdos estomacais indicou que $70 \%$ dos itens consumidos são autóctones, 24\% alóctones e 6\% de origem não identificada, sendo a maioria das espécies invertívoras. A autora constatou que a 
comunidade se mostrou estruturada em nível espacial, temporal e trófico, apresentando um uso partilhado dos recursos alimentares disponíveis.

Dufech et al. (2003) compararam a dieta de duas populações de Mimagoniates rheocharis em dois córregos da bacia do rio Tramandaí (RS). Os recursos mais utilizados pela espécie nos locais distintos e nas diversas classes de tamanho, foram basicamente insetos terrestres sendo, assim, caracterizada como insetívora. Os autores concluem que o ambiente de floresta ao redor das áreas amostradas é diretamente responsável pela alimentação e sobrevivência das populações desta espécie.

De acordo com Esteves \& Aranha (1999), o estudo das relações tróficas em riachos pode levar a formulação de diversos conceitos e teorias relativos aos ambientes aquáticos. No entanto, além da produção do conhecimento faz-se necessária também a aplicação destes novos conceitos e teorias aos estudos de riachos brasileiros.

Este trabalho contribui para o aumento de informações sobre a alimentação de peixes em riachos, e somando-se ao conhecimento dos trabalhos aqui citados e aos demais que estão em andamento, este conjunto pode oferecer subsídios para pesquisas aplicadas, que utilizem abordagens holísticas sobre as interações ecológicas nestes ambientes. 


\section{MATERIAL E MÉTODOS}

\section{1 Área de estudo}

A bacia do rio Passa-Cinco está localizada na região centro-leste do Estado de São Paulo, sendo a maior sub-bacia pertencente à bacia do rio Corumbataí, com 52.757,6 ha (Valente, 2001), o qual faz parte da bacia do rio Piracicaba, incluída na drenagem do alto rio Paraná (Figura 2). Esta sub-bacia é composta por dois rios principais: o rio da Cabeça, que deságua no rio Passa-Cinco, e este, por sua vez, no rio Corumbataí.

Sua orogenia data do período Cenozóico, tendo as cabeceiras localizadas nas cuestas da Serra Geral. A topografia é colinosa, com vegetação original composta por cerrado e floresta estacional semi-decidual (Koffler, 1993).Atualmente, a bacia do rio Passa-Cinco possui 51,72\% de sua superfície ocupada por áreas de pastagem implantada, 14,13\% por cana-de-açúcar, $15,67 \%$ por floresta nativa e $0,74 \%$ por cerrado (Valente, 2001).

Os córregos escolhidos para as coletas dos peixes foram selecionados por dois critérios. O primeiro deles foi a presença de mata (córregos Paredão e Jibóia) ou pasto (Cantagalo e Anzol) em uma faixa de 30 metros a partir de ambas as margens em toda a rede de canais à montante do ponto de amostragem. O segundo critério para a escolha foi o tipo de substrato dominante, córregos assoreados percorrendo fragmentos de mata nativa (Vereador e Areião), e córregos de substrato rochoso percorrendo fragmentos de mata ou pasto (Paredão, Jibóia, Cantagalo e Anzol). Os nomes dados aos córregos Paredão, Jibóia, Areião e Vereador são fictícios, pois segundo a carta topográfica formulada pelo Instituto Brasileiro de Geografia (IBGE), os mesmos não apresentam nomes próprios. 


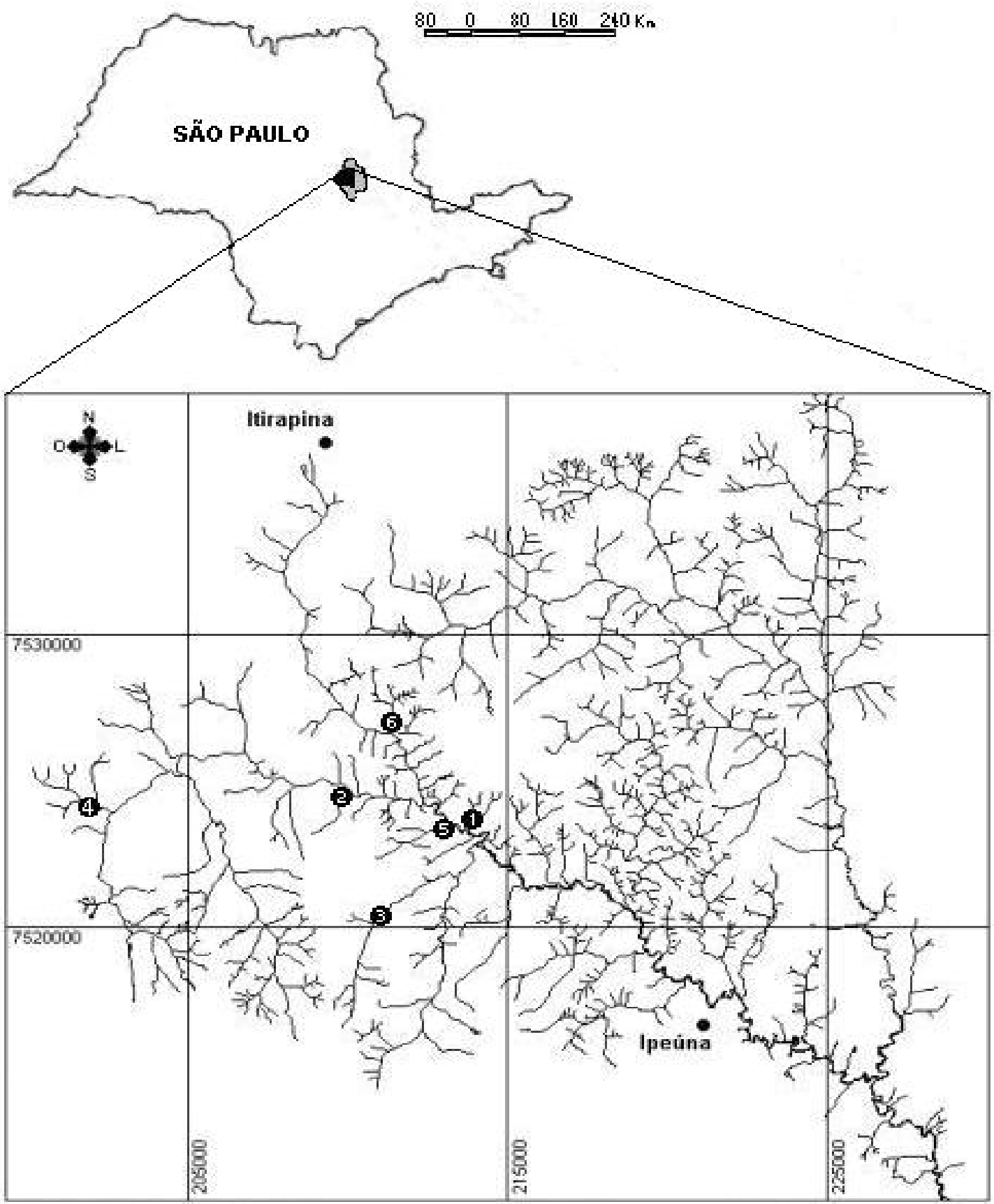
(1) Córrego "Paredăo"
2 Córrego "Jibóia"
(3) Córrego Cantagalo
4. Córrego do Anzol

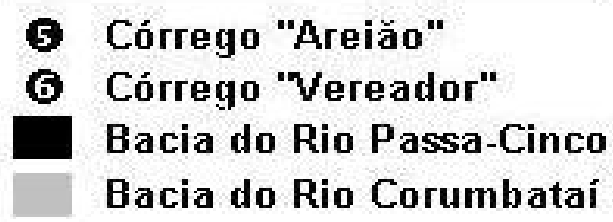

Figura 2 - Localização da bacia do rio Passa-Cinco no Estado de São Paulo, indicando os pontos de coleta 


\subsubsection{Dados ambientais}

Nos locais de coletas foram realizadas medidas ambientais (Tabela 1) e a classificação dos tipos de substratos encontrados nos diversos córregos, seguiu a Escala de Wentworth (Tabela 2).

Tabela 1. Características físico-químicas e bióticas amostrados no momento da coleta dos peixes nos córregos da bacia do rio Passa-Cinco

\begin{tabular}{|c|c|c|c|c|c|c|}
\hline & Paredão & Jibóia & Cantagalo & Anzol & Areião & Vereador \\
\hline Temperatura da água (C) & 21,4 & 22,5 & 24,4 & 25,4 & 26,3 & 25,6 \\
\hline Oxigênio dissolvido (mg/L) & 7,8 & 8,1 & 7,8 & 7,7 & 7,3 & 7,1 \\
\hline Condutividade $\left(\mu \mathrm{S} \mathrm{cm}{ }^{-1}\right)$ & 60 & 80 & 60 & 50 & 60 & 80 \\
\hline $\mathrm{pH}$ & 7,4 & 7,6 & 7,4 & 7,1 & 7,4 & 6,6 \\
\hline Uso do corredor ripário & mata & mata & pasto & pasto & mata & mata \\
\hline Largura média (m) & 2,7 & 1,61 & 4,98 & 1,63 & 3,31 & 1,98 \\
\hline Profundidade média (cm) & 11,9 & 6,3 & 9,4 & 11,4 & 3,9 & 5,7 \\
\hline Substrato & $\begin{array}{c}\text { matacão- } \\
\text { areia }\end{array}$ & $\begin{array}{l}\text { areia- } \\
\text { matacão }\end{array}$ & $\begin{array}{l}\text { seixo- } \\
\text { matacão }\end{array}$ & matacão & areia & areia \\
\hline $\mathrm{N}^{0}$ de árvores pendentes & 147 & 107 & 0 & 1 & 85 & 77 \\
\hline
\end{tabular}

Fonte: Processo FAPESP 00/14284-0.

Tabela 2. Classificação dos substratos minerais por tamanho de partícula

\begin{tabular}{ll}
\hline Substrato mineral & Diâmetro da partícula $(\mathrm{mm})$ \\
\hline Silte & $<0,063$ \\
Areia & $0,125-2$ \\
Cascalho & $2-16$ \\
Seixo & $16-64$ \\
Matacão & $64-128$ \\
Bloco & $>256$. \\
\hline
\end{tabular}

Fonte: Allan (1995).

A determinação da composição vegetativa do corredor ripário foi realizada através de visitas prévias a campo e da utilização de dados de informações cartográficas digitais (Projeto Corumbataí, 2001), através da geração de um Plano de Informação (PI) contendo um "buffer" de $30 \mathrm{~m}$ de largura em torno dos córregos amostrados, simulando às Áreas de Preservação Permanente (APP) (CONAMA, 2002) (Tabela 3). As microbacias onde foram realizadas as amostragens na bacia do rio Passa-Cinco estão caracterizadas a seguir. 
Tabela 3. Porcentagem de uso do solo do corredor ripário dos córregos amostrados na bacia do rio Passa-Cinco

\begin{tabular}{lccccc}
\hline & Mata & Pasto & Floresta Plantada & Cana & Outros \\
\hline Paredão & $\mathbf{5 9}$ & 38 & 3 & 0 & 0 \\
Jibóia & $\mathbf{5 3}$ & 24 & 17 & 0 & 6 \\
Cantagalo & 26 & $\mathbf{5 3}$ & 7 & 11 & 3 \\
Anzol & 24 & $\mathbf{6 3}$ & 8 & 4 & 1 \\
Areião & $\mathbf{5 8}$ & 42 & 0 & 0 & 0 \\
Vereador & $\mathbf{7 4}$ & 18 & 8 & 0 & 0 \\
\hline
\end{tabular}

Fonte: Processo FAPESP 00/14284-0.

Córrego Paredão (22 22’02”S; 47 46’43”W): a cobertura do solo predominante na microbacia é pasto, possuindo aproximadamente $30 \mathrm{~m}$ em ambas margens de vegetação ripária constituída por mata secundária, formando um dossel sobre o córrego. Visualmente o canal apresentava-se quase que totalmente sombreado (70\%), com pouca vegetação pendente sob a água, constituída basicamente por raízes das árvores próximas ao canal. Neste local, o substrato é constituído principalmente por matacões e areia, ocorrendo seqüências de corredeira e "run” (ou corredores) e poucos poços formados geralmente atrás de grandes blocos e lateralmente, ao longo de paredões de pedra de rocha matriz que ocorrem junto às margens.

Córrego Jibóia (22 21’37’S; 47 49’08’W): a cobertura do solo predominante na microbacia é de mata e o corredor ripário constituído principalmente por mata secundária, possuindo um canal bem sombreado (70\%) e com pouca vegetação pendendo sob a água, constituída de raízes e gramíneas. O substrato do trecho de coleta é formado principalmente por areia, matacões e considerável presença de matéria vegetal, como troncos, galhos e acúmulos de folhas, apresentando seqüências de corredeira, "run” e poços, formados pelos troncos e galhos.

Córrego Cantagalo (22 24’06”S; 47²8’38’W): o predomínio da cobertura do solo na microbacia é de pasto e o corredor ripário é constituído por pastagem limpa e sem árvores pendentes sobre o canal, permitindo a incidência de luz solar direta sobre o leito do córrego. O substrato deste local é formado principalmente por seixos e matacões, apresentando corredeiras na maior parte dos trechos amostrados, sendo que as 
gramíneas nas margens ficam pendentes sob a água, ocorrendo a passagem de gado na área.

Córrego do Anzol (22 21’46”S; 4753’29”W): a cobertura do solo predominante na microbacia é de pasto, presente também no corredor ripário. Aparecem algumas árvores, permitindo a incidência de luz solar direta sobre o leito do córrego. Alguns trechos apresentam barrancos altos, com até $3 \mathrm{~m}$ e o substrato do local de amostragem é formado basicamente por matacões, possuindo seqüências de corredeiras e "run" e pequenos poços, exceto ao lado das barrancas mais altas onde ocorrem remansos. A pouca vegetação pendente sob a água é constituída por gramíneas, ocorrendo também a presença de gado na área.

Córrego Areião (22 22’15”s; 47 47’23”W): a cobertura do solo da microbacia predomina pasto, mas os trechos amostrados apresentavam um corredor ripário constituído por mata secundária, apresentando um sombreamento do canal de 70 a 80\%. O córrego está severamente assoreado, onde a mata ripária está sendo afogada em grande parte do trecho amostrado devido ao soerguimento do canal e consequente elevação do lençól freático. Em alguns trechos de maior declive, onde o córrego é mais encaixado, aparecem poucos blocos e matacões formando corredeiras mas, à montante, o córrego passa por trechos de pastagem e à jusante o canal não é definido, apresentando pouca água visível. A vegetação pendente sob a água é formada por raízes, principalmente de arbustos e gramíneas.

Córrego Vereador (22 20’16”S; 47 48’11”W): a cobertura do solo predominante na microbacia é de mata, sendo que em alguns trechos amostrados, a mata forma um dossel sobre o canal e em outros trechos o corredor ripário é constituído por arbustos e pasto sujo, permitindo maior incidência de luz. Este córrego também encontra-se bastante assoreado, não possuindo alternância de habitats entre poços e corredeiras. A vegetação pendente sob a água é formada por raízes, principalmente de arbustos e gramíneas.

Estes dados foram obtidos através de observações realizadas pelo “in loco” e através dos resultados do projeto "Comunidades de peixes de riachos em função da 
paisagem da Bacia do Rio Piracicaba, Estado de São Paulo” (Processo FAPESP 00/14284-0).

\subsection{Dieta}

\subsubsection{Coleta de dados}

Os peixes foram coletados no período de fevereiro a abril de 2003, utilizando métodos combinados de pesca elétrica, redes de arrasto manual e peneiras, sempre no período vespertino. Logo após a captura, os peixes foram fixados em formol 10\%.

Os exemplares de A. paranae foram conservados em álcool 70\% e identificados com base em artigos e chaves dicotômicas específicas (Godoy, 1975; Britski et al., 1988; Garutti \& Britski, 2000). A confirmação da determinação da espécie foi feita no Museu de Zoologia da USP. Os exemplares capturados foram medidos (comprimento padrão), pesados, eviscerados e os estômagos preservados em álcool 70\%.

\subsubsection{Análise da dieta}

Foram analisados 180 estômagos de A. paranae (30 estômagos por local) que apresentavam conteúdo alimentar, sob microscópio estereoscópico e óptico. Os itens foram identificados até o menor nível taxonômico possível, de acordo com o estado de conservação dos mesmos. Na identificação dos itens de origem animal, consultaram-se os trabalhos de Borror \& DeLong (1969), McCafferty (1981), Stehr (1987), Merrit \& Cummins (1996) e Ruppert \& Barnes (1996). Para identificação das algas foram utilizados os trabalhos de Bicudo \& Bicudo (1970) e Prescott (1982).

O conteúdo de cada estômago foi analisado de acordo com os métodos de freqüências de ocorrência e volumétrica (Hyslop, 1980):

1. Freqüência de Ocorrência: foi obtida registrando-se o número de peixes em que cada item ocorreu, obtendo-se a porcentagem do total de itens registrados, sendo calculada pela seguinte fórmula:

$$
F_{i}=\frac{\left(n_{i} \times 100\right)}{N}
$$

onde: 
$F_{i}$ : freqüência de ocorrência do item alimentar $i$ na amostra; $n_{i}$ : número de estômagos da amostra que contém o item alimentar $i$; $N$ : número total de estômagos com conteúdos na amostra.

2. Freqüência Volumétrica: foi obtida relacionando-se o volume de cada item com o volume total dos itens no estômago, obtendo-se a porcentagem de cada conteúdo gástrico. O volume foi obtido pela compressão do material (itens alimentares) com lâmina de vidro sobre placa milimetrada até uma altura conhecida $(1 \mathrm{~mm})$, e o resultado convertido em mililitros $\left(1 \mathrm{~mm}^{3}=0,001 \mathrm{~mL}\right)$ (Hellawel \&Abel, 1971).

\subsubsection{Análise dos dados da dieta}

Os itens alimentares (representados pela freqüência volumétrica) utilizadas pela espécie nos distintos locais, foram agrupadas nas seguintes categorias taxonômicas (recursos alimentares) e/ou ecológicas amplas (Sabino \& Castro, 1990): inseto aquático, inseto terrestre, invertebrado terrestre, vegetal terrestre, algas e outros (itens com pequenos volumes). Estes dados também foram agrupados de acordo com sua origem: autóctones (itens endógenos), alóctones (itens exógenos) e mista (itens impossíveis de identificar quanto à origem).

Para determinar a importância dos recursos alimentares e a categoria trófica da espécie nos locais de amostragem, foi utilizada a relação entre as porcentagens de freqüências de ocorrência e de volume, de cada grupo, representada graficamente de acordo com Costello (1990). Este método consiste na plotagem dos valores de volume no eixo y e ocorrência no eixo x. Os pontos posicionados próximos a 100\% de ocorrência e volume apresentam os grupos alimentares dominantes; pontos posicionados próximos a $100 \%$ de ocorrência e $1 \%$ de volume indicam que o predador consome diferentes presas em baixa quantidade, sendo considerado um generalista trófico; ao contrário, pontos posicionados próximos a 1\% de ocorrência e 100\% de volume indicam que o predador é especialista trófico.

A amplitude do nicho alimentar foi calculada por local utilizando-se a medida de Levins (Krebs, 1999), com o pressuposto que a amplitude da dieta possa ser estimada 
pela medida da uniformidade da distribuição dos itens entre os diversos recursos alimentares. Estes dados referem-se aos valores brutos de ocorrência e volume dos itens alimentares, calculados pelo programa Ecological Methodology versão 6.1 (Exeter Software ${ }^{\circledR}$ ), dado pela fórmula:

$$
B=\frac{1}{\sum p_{j}^{2}}
$$

onde:

$B$ : amplitude do nicho alimentar; $p_{j}$ : proporção do item $j$ na dieta total.

Para uniformizar a medida do nicho trófico (variando de 0 a 1), aplicou-se a fórmula de Hurbert (1978), sendo que os valores também foram obtidos através do programa Ecological Methodology versão 6.1 (Exeter Software ${ }^{\circledR}$ ).

$$
B_{A}=\frac{B-1}{n-1}
$$

onde:

$B_{A}$ : amplitude do nicho alimentar padronizada; $B$ : amplitude do nicho alimentar; $n$ : número total de itens alimentares consumidos.

A atividade alimentar da espécie foi avaliada pelo grau de repleção (GR) dos estômagos no período de captura, seguindo a escala: $0=$ vazio; $1=$ parcialmente vazio (estômago 25\% preenchido); 2 = parcialmente cheio (estômago preenchido entre 25 e 75\%) e 3 = completamente cheio (estômago preenchido entre 75 e 100\%) (Hahn et al., 1997). Para melhor visualização da representação gráfica dos dados, os graus de repleção 0-1 e 2-3 foram agrupados.

As categorias alimentares utilizadas pelos peixes foram ordenadas de acordo com os locais de coleta, usando uma Análise de Correspondência Destendenciada (DCA) (Jongman et al., 1995). Nesta análise utilizou-se a freqüência volumétrica, sendo feita com o auxílio do pacote estatístico PC-Ord versão 2.0 (McCune \& Mefford, 1995). 
Os resultados da análise dos conteúdos gástricos foram analisados por riacho, visando detectar-se padrões de similaridade entre eles. Para tanto, foi utilizada uma análise de agrupamento, utilizando-se o algorítimo da Distância de Manhattan como coeficiente de similaridade e o UPGMA como método de ligação. Esta análise foi realizada utilizando os escores provenientes da DCA através do programa Statistica StatSoft ${ }^{\circledR}$ versão 5.0 .

\subsection{Disponibilidade de recursos alimentares no ambiente}

\subsubsection{Coleta das amostras}

As amostragens dos itens passíveis de serem consumidos por A. paranae foram realizadas antes de serem coletados os peixes, para que não houvesse distúrbio no ambiente. Para amostrar os invertebrados que caem na água, foram utilizadas 10 bandejas plásticas de retenção (área total de $0,9 \mathrm{~m}^{2}$ ), pintadas na cor marrom, parcialmente cheias de água do próprio córrego com algumas gotas de detergente. Também foram utilizadas 3 redes de deriva, com malha de abertura de $125 \mu \mathrm{m}$ e dimensões de 43x28 cm de diâmetro, para captura de material arrastado, tanto de origem alóctone quanto autóctone. Estes aparelhos foram colocados no início da manhã (aproximadamente às 8:00h) e retirados no final da tarde (aproximadamente às 17:00h), permanecendo no ambiente em média 9 horas.

Para amostrar os organismos presentes na vegetação suspensa das margens na água, utilizou-se uma rede de mão, com malha de $125 \mu \mathrm{m}$ e área de 0,10 $\mathrm{m}^{2}$. Já para captura dos invertebrados bentônicos, empregou-se um amostrador tipo Surber com malha de $125 \mu \mathrm{m}$ e área de $0,09 \mathrm{~m}^{2}$, colocando-o contra a corrente e revolvendo o fundo à sua frente com as mãos durante 3 minutos. Todas as amostras foram fixadas imediatamente em formol $4 \%$.

\subsubsection{Processamento das amostras}

O material obtido em cada uma destas amostragens foi despejado em peneiras de granulometria (malhas de 500 e $250 \mu \mathrm{m}$ ), lavado em água corrente e conservado em álcool 70\%. Posteriormente, o conteúdo de ambas peneiras foi triado sob microscópio 
estereoscópico, separado e identificado até o nível de ordem. Organismos da Ordem Diptera foram identificados até o nível de família, baseando-se nos trabalhos de Borror \& Delong (1969), McCafferty (1981), Stehr (1987) e Merrit \& Cummins (1996).

\subsubsection{Análise dos dados}

Para determinar a diversidade de invertebrados encontrados nos córregos estudados, aplicou-se o Índice de Diversidade de Shannon ( $\left.H^{\prime}\right)$ (Magurran, 1988):

$$
H^{\prime}=-\sum_{i=1}^{S}\left[\left(\frac{n_{i}}{n}\right) \ln \left(\frac{n_{i}}{n}\right)\right]
$$

onde:

$n_{i}$ : número de itens da categoria $i ; n$ : número total de itens.

Para avaliar a seleção dos recursos por A. paranae, estabeleceu-se a relação entre a proporção dos itens consumidos pela espécie com a proporção dos itens disponíveis no ambiente, utilizando-se o Índice de Eletividade $\left(E_{i}\right)$ de Ivlev (1961):

$$
E_{i}=\frac{\left(r_{i}-p_{i}\right)}{\left(r_{i}+p_{i}\right)}
$$

onde:

$E_{i}$ : eletividade do item alimentar $i ; r_{i}$ : proporção dos itens consumidos; $p_{i}$ : proporção dos itens disponíveis.

Os valores de $E_{i}$ podem variar de -1 a +1 , indicando evitação ou preferência, respectivamente. Valores próximos a zero, indicam que o item foi ingerido na mesma proporção que aquela encontrada no ambiente. A análise de eletividade foi realizada para cada riacho local visando inferir sobre a preferência alimentar da espécie, sendo utilizados os invertebrados encontrados nos conteúdos gástricos e no ambiente. 


\section{RESULTADOS}

\subsection{Dieta}

O tamanho dos espécimes de $A$. paranae utilizados nas análises dos conteúdos gástricos variou de 1,69 a 6,07 cm, apresentando uma média geral no comprimento padrão de 3,64 cm (Tabela 4).

Tabela 4. Comprimento padrão médio e número de exemplares de $A$. paranae analisados nos córregos da bacia do rio Passa-Cinco, SP

\begin{tabular}{lccc}
\hline \multicolumn{1}{c}{ Córregos } & Amplitude & Média & $\mathrm{N}$ \\
\hline Paredão & $2,42-6,07 \mathrm{~cm}$ & $4,31 \pm 1,11$ & 30 \\
Jibóia & $1,92-5,18 \mathrm{~cm}$ & $2,91 \pm 0,84$ & 30 \\
Cantagalo & $2,86-6,05 \mathrm{~cm}$ & $4,08 \pm 0,83$ & 30 \\
Anzol & $1,69-5,46 \mathrm{~cm}$ & $3,44 \pm 1,05$ & 30 \\
Areião & $2,19-5,61 \mathrm{~cm}$ & $3,46 \pm 0,83$ & 30 \\
Vereador & $1,80-5,92 \mathrm{~cm}$ & $3,68 \pm 1,02$ & 30 \\
& - & 3,64 & 180 \\
\hline
\end{tabular}

Os itens alimentares consumidos por A. paranae nos diferentes córregos da bacia do rio Passa-Cinco estão apresentados na Tabela 3. Através da análise gráfica de Costello (1990), verifica-se que no Córrego Paredão a categoria alimentar dominante foi de insetos terrestres (Figura 3). Os maiores valores de ocorrência e volume, respectivamente, foram Formicidae (50,0 e 17,7\%), Coleoptera (33,3 e 26,3\%) e Hymenoptera (33,3 e 12,9\%), todos terrestres (Tabela 3). No Córrego Jibóia, a espécie consumiu maior variedade de recursos, representados por insetos terrestres, insetos aquáticos, vegetais terrestres e invertebrados terrestres, registrando-se maior ocorrência para Formicidae (80,0\%), ninfas de Ephemeroptera (53,3\%) e Fruto/semente (53,3\%). Quanto ao volume, destacou-se Oligochaeta (39,5\%) (Tabela 3). 
Tabela 5. Porcentagens de ocorrência (O) e de volume (V) dos itens alimentares consumidos por Astyanax paranae em seis córregos da bacia do rio Passa-Cinco, SP ( $\mathrm{n}=$ ninfa, l= larva, $\mathrm{p}=$ pupa, a= adulto)

\begin{tabular}{|c|c|c|c|c|c|c|c|c|c|c|c|c|}
\hline \multirow{2}{*}{ ITENS } & \multicolumn{2}{|c|}{ Paredão } & \multicolumn{2}{|c|}{ Jibóia } & \multicolumn{2}{|c|}{ Cantagalo } & \multicolumn{2}{|c|}{ Anzol } & \multicolumn{2}{|c|}{ Areião } & \multicolumn{2}{|c|}{ Vereador } \\
\hline & $\mathrm{O}$ & $\mathrm{V}$ & $\mathrm{O}$ & $\mathrm{V}$ & $\mathrm{O}$ & $\mathrm{V}$ & $\mathrm{O}$ & $\mathrm{V}$ & $\mathrm{O}$ & $\mathrm{V}$ & $\mathrm{O}$ & $\mathrm{V}$ \\
\hline \multicolumn{13}{|l|}{ AUTÓCTONES } \\
\hline \multicolumn{13}{|l|}{ Origem Animal } \\
\hline Tecameba & & & & & & & 16,7 & 0,2 & & & & \\
\hline Nematoda & 3,3 & $*$ & 10,0 & $*$ & 6,7 & 0,1 & & & & & & \\
\hline Isopoda & & & 6,7 & 1,1 & & & & & & & & \\
\hline Ephemeroptera (n) & 10,0 & 0,1 & 53,3 & 2,2 & 56,7 & 12,6 & 56,7 & 8,8 & 20,0 & 1,1 & 3,3 & 0,1 \\
\hline Odonata (n) & & & 10,0 & 1,1 & & & & & 3,3 & 23,0 & & \\
\hline Plecoptera (n) & & & 6,7 & 0,1 & & & 3,3 & 0,2 & & & & \\
\hline Hemiptera $(n+a)$ & 3,3 & 0,1 & 3,3 & $*$ & 3,3 & 2,3 & 3,3 & 0,1 & & & 10,0 & 0,9 \\
\hline Megaloptera (l) & & & & & & & & & 3,3 & 0,8 & & \\
\hline Coleoptera (l+a) & 6,7 & 0,3 & 13,3 & 0,2 & & & & & 3,3 & 0,1 & 10,0 & 5,7 \\
\hline Diptera (l) & & & 16,7 & 0,3 & 43,3 & 1,9 & 3,3 & 0,1 & 10,0 & 1,0 & 6,7 & 0,3 \\
\hline Diptera (p) & 20,0 & 0,7 & & & 53,3 & 3,5 & 26,7 & 1,4 & & & 6,7 & 0,1 \\
\hline Chironomidae (l) & 30,0 & 0,4 & 20,0 & 0,2 & 53,3 & 2,9 & 66,7 & 3,4 & 3,3 & 0,1 & 20,0 & 0,1 \\
\hline Simuliidae (l) & & & 40,0 & 2,7 & 20,0 & 0,9 & 13,3 & 0,3 & & & 13,3 & 0,3 \\
\hline Simuliidae (p) & & & & & 33,3 & 1,6 & 3,3 & 0,2 & & & 3,3 & 0,1 \\
\hline Trichoptera (l) & 10,0 & 1,3 & 30,0 & 1,2 & 83,3 & 37,6 & 6,7 & 0,3 & 6,7 & 1,2 & & \\
\hline Lepidoptera (l) & 3,3 & 2,8 & 10,0 & 19,2 & & & & & & & 6,7 & 0,1 \\
\hline Escama de peixe & & & & & 3,3 & 0,2 & 6,7 & 0,4 & 3,3 & 0,1 & & \\
\hline \multicolumn{13}{|l|}{ Origem Vegetal } \\
\hline Desmidia & & & & & & & 10,0 & 0,1 & & & & \\
\hline Pennales & & & & & & & 10,0 & 0,1 & & & & \\
\hline Oedogonium sp. & & & & & & & 6,7 & 1,7 & & & & \\
\hline Spirogyra sp. & & & & & & & 43,3 & 12,5 & & & & \\
\hline
\end{tabular}


Tabela 5. Porcentagens de ocorrência (O) e de volume (V) dos itens alimentares consumidos por Astyanax paranae em seis córregos da bacia do rio Passa-Cinco, SP ( $n=$ ninfa, l= larva, $\mathrm{p}=$ pupa, a= adulto)

\begin{tabular}{|c|c|c|c|c|c|c|c|c|c|c|c|c|}
\hline \multirow{2}{*}{ ITENS } & \multicolumn{2}{|c|}{ Paredão } & \multicolumn{2}{|c|}{ Jibóia } & \multicolumn{2}{|c|}{ Cantagalo } & \multicolumn{2}{|c|}{ Anzol } & \multicolumn{2}{|c|}{ Areião } & \multicolumn{2}{|c|}{ Vereador } \\
\hline & $\mathrm{O}$ & $\mathrm{V}$ & $\mathrm{O}$ & $\mathrm{V}$ & $\mathrm{O}$ & $\mathrm{V}$ & $\mathrm{O}$ & $\mathrm{V}$ & $\mathrm{O}$ & $\mathrm{V}$ & $\mathrm{O}$ & $\mathrm{V}$ \\
\hline \multicolumn{13}{|l|}{ ALÓCTONES } \\
\hline \multicolumn{13}{|l|}{ Origem Animal } \\
\hline Oligochaeta & & & 13,3 & 39,5 & & & & & & & & \\
\hline Scorpionida & & & 37,3 & $*$ & & & & & & & & \\
\hline Aranae & 6,7 & 0,4 & 33,3 & 2,1 & 3,3 & 0,3 & 10,0 & 0,9 & 16,7 & 2,0 & 3,3 & 0,5 \\
\hline Collembola & & & 16,7 & 0,1 & 3,3 & 0,1 & 3,3 & * & & & 6,7 & * \\
\hline Odonata (a) & 3,3 & 0,4 & & & & & & & & & 3,3 & 2,7 \\
\hline Blattodea (a) & & & & & & & & & 3,3 & 0,7 & & \\
\hline Orthoptera (a) & & & 6,7 & 1,2 & 3,3 & 0,4 & 10,0 & 24,5 & & & 3,3 & 1,2 \\
\hline Hemiptera $(\mathrm{n}+\mathrm{a})$ & & & 23,3 & 1,0 & 20,0 & 6,0 & 3,3 & 0,5 & 16,7 & 7,5 & 10,0 & 0,6 \\
\hline Coleoptera (a) & 33,3 & 26,3 & 36,7 & 3,6 & 6,7 & 0,9 & 10,0 & 1,1 & 33,3 & 7,1 & 13,3 & 3,3 \\
\hline Diptera (a) & 20,0 & 1,4 & 33,3 & 0,7 & & & 3,3 & 0,4 & 13,3 & 1,4 & & \\
\hline Trichoptera (a) & & & 13,3 & 2,5 & 3,3 & 0,6 & 3,3 & 1,8 & 6,7 & 8,3 & 3,3 & 0,1 \\
\hline Lepidoptera (a) & 3,3 & 0,1 & 3,3 & 0,2 & & & & & 3,3 & 0,2 & & \\
\hline Lepidoptera (l) & 10,0 & 23,0 & 3,3 & 0,1 & & & & & 16,7 & 18,3 & 23,3 & 51,4 \\
\hline Hymenoptera (a) & 33,3 & 12,9 & 13,3 & 0,9 & 3,3 & 3,3 & 10,0 & 0,8 & 10,0 & 2,1 & 3,3 & 0,5 \\
\hline Formicidae (a) & 50,0 & 17,7 & 80,0 & 9,3 & 26,7 & 6,7 & 53,3 & 27,3 & 70,0 & 18,1 & 50,0 & 18,6 \\
\hline Fragmentos de insetos & & & & & & & & & 6,7 & 0,5 & 13,3 & 0,7 \\
\hline \multicolumn{13}{|l|}{ Origem Vegetal } \\
\hline Monocotiledônea & & & & & 33,3 & 10,2 & 16,7 & 1,0 & & & & \\
\hline Dicotiledônea & 16,7 & 8,3 & 10,0 & 0,7 & 3,3 & 0,1 & 3,3 & 1,1 & 3,3 & * & & \\
\hline Fruto/Semente & 20,0 & 1,8 & 53,3 & 9,8 & 50,0 & 7,6 & 26,7 & 7,9 & 40,0 & 6,1 & 60,0 & 12,8 \\
\hline MISTOS & & & & & & & & & & & & \\
\hline Detrito vegetal & 6,7 & 2,0 & & & & & 10,0 & 2,7 & & & & \\
\hline Sedimento & & & & & 3,3 & 0,2 & 3,3 & 0,3 & 6,7 & 0,4 & & \\
\hline
\end{tabular}



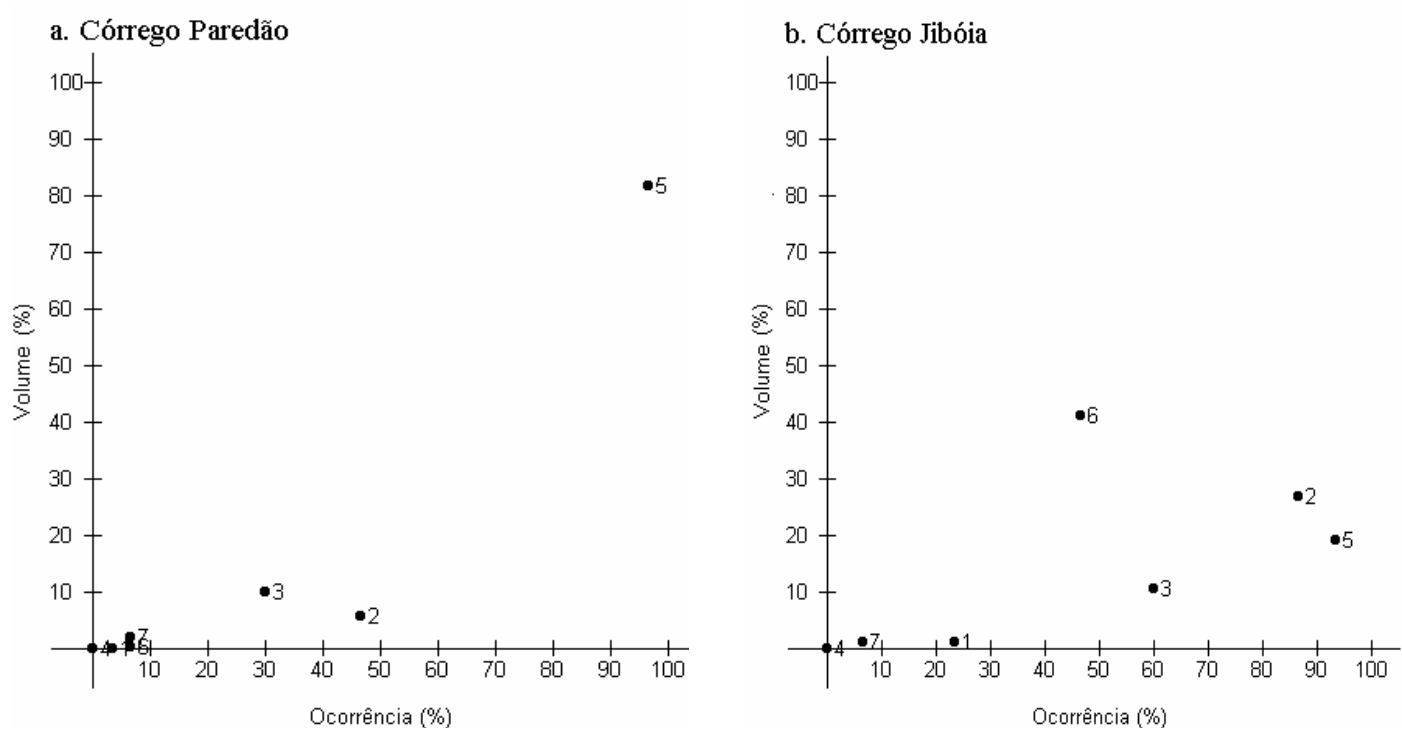

Figura 3 - Freqüência de ocorrência e volumétrica dos recursos alimentares utilizados por $A$. paranae nos córregos a) Paredão e b) Jibóia. 1 = outros, 2 = inseto aquático, $3=$ vegetal terrestre, $4=$ algas, $5=$ inseto terrestre, $6=$ invertebrado terrestre e $7=$ detrito/sedimento

No Córrego Cantagalo, as categorias alimentares mais representativas foram insetos aquáticos e vegetais terrestres (Figura 4). Os maiores percentuais de ocorrência e volume, foram representados respectivamente por Trichoptera (83,3 e 37,6\%) e Ephemeroptera (56,7 e 12,6\%). Larvas de Chironomidae e pupas de Diptera, ambas com $53,3 \%$, frutos e sementes (50,0\%) e monocotiledôneas (33,3\%) apresentaram valores expressivos de ocorrência (Tabela 3). No Córrego do Anzol, insetos terrestres, insetos aquáticos e algas foram os itens mais importantes (Figura 4), sobressaindo-se Formicidae, com 53,3 e 27,3\% em ocorrência e volume, respectivamente. Nos valores de ocorrência, destacaram-se ainda larvas de Chironomidae (66,7\%), ninfas de Ephemeroptera (56,7\%) e Spirogyra sp. (43,3\%) (Tabela 3).

No Córrego Areião, a espécie consumiu maior quantidade de insetos terrestres (Figura 5), representado principalmente por Formicidae (70,0\% em ocorrência e 18,1\% em volume) (Tabela 3). Já no Córrego Vereador, houve um predomínio marcante tanto de insetos terrestres quanto de vegetais terrestres na dieta da espécie (Figura 5). As maiores ocorrências foram de Fruto/semente (60,0\%) e Formicidae (50,0\%) e com relação ao volume, larvas de Lepidoptera (51,4\%) (Tabela 3). 

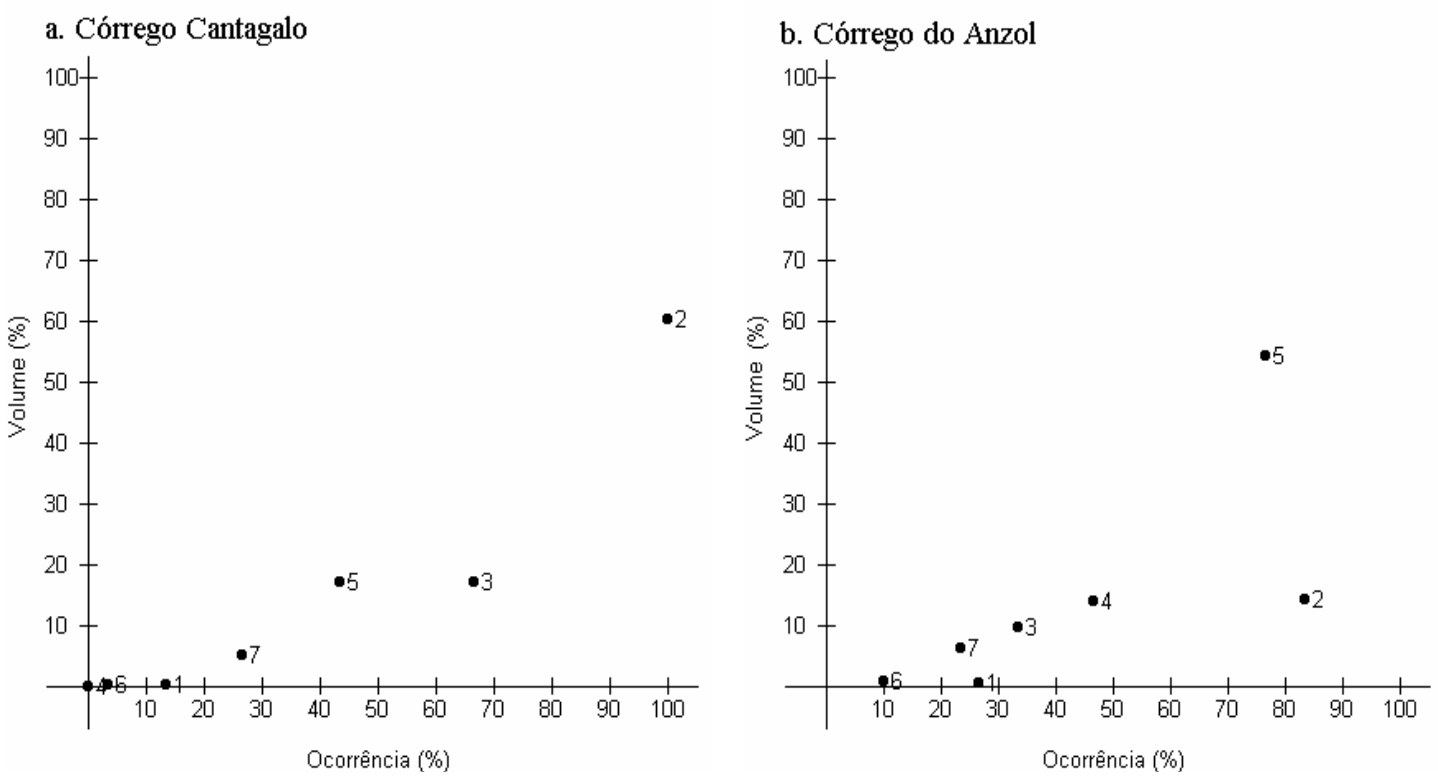

Figura 4 - Freqüência de ocorrência e volumétrica dos recursos alimentares utilizados por $A$. paranae nos córregos a) Cantagalo e b) Anzol. 1 = outros, 2 = insetos aquáticos, $3=$ vegetal terrestre, $4=$ algas, $5=$ insetos terrestres, $6=$ invertebrados terrestres e $7=$ detrito/sedimento
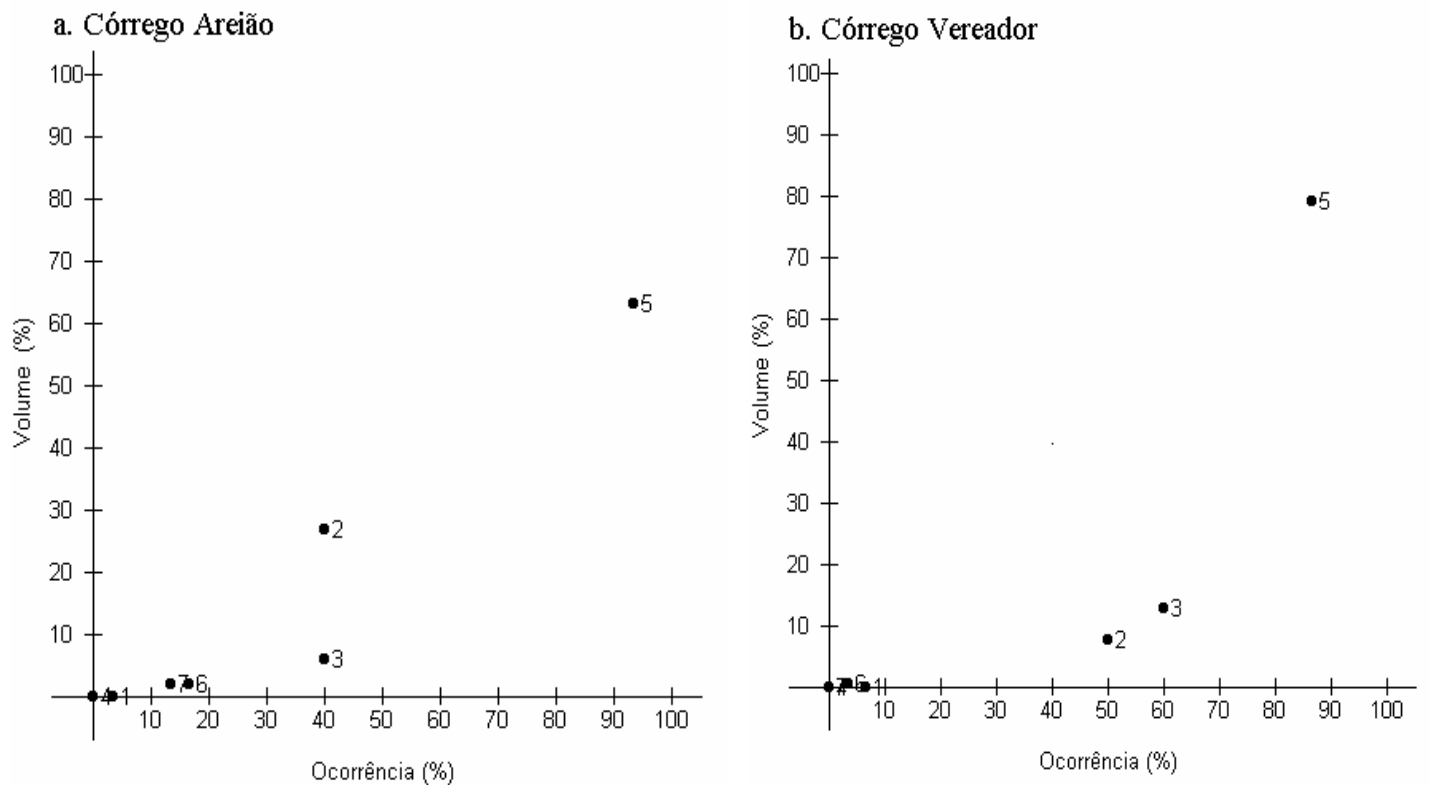

Figura 5 - Freqüência de ocorrência e volumétrica dos recursos alimentares utilizados por $A$. paranae nos córregos a) Areião e b) Vereador. 1 = outros, $2=$ insetos aquáticos, $3=$ vegetal terrestre, $4=$ algas, $5=$ insetos terrestres, $6=$ invertebrados terrestres e $7=$ detrito/sedimento 
Com relação à origem dos alimentos, observou-se que os recursos alóctones compuseram a maior parte da dieta de A. paranae nos córregos Paredão (92,3\%), Vereador (92,3\%), Areião (72,2\%) , Jibóia (71,6\%) e Anzol (67,2\%). Apenas no Córrego Cantagalo os recursos autóctones predominaram, com 63,6\% (Figura 6).

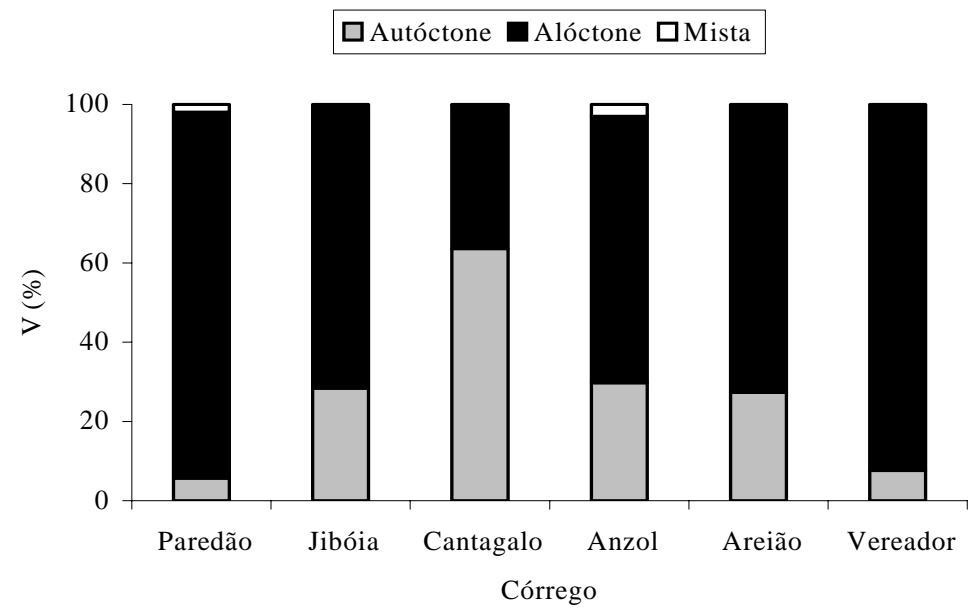

Figura 6 - Freqüência volumétrica (V\%) da origem dos itens alimentares na dieta de $A$. paranae nos diferentes córregos da bacia do rio Passa-Cinco, SP

Os maiores valores de amplitude de nicho trófico foram registrados nos córregos Paredão e Jibóia, enquanto que nos córregos Anzol, Areião e Vereador, os espécimes apresentaram menor amplitude de exploração dos recursos alimentares (Figura 7).

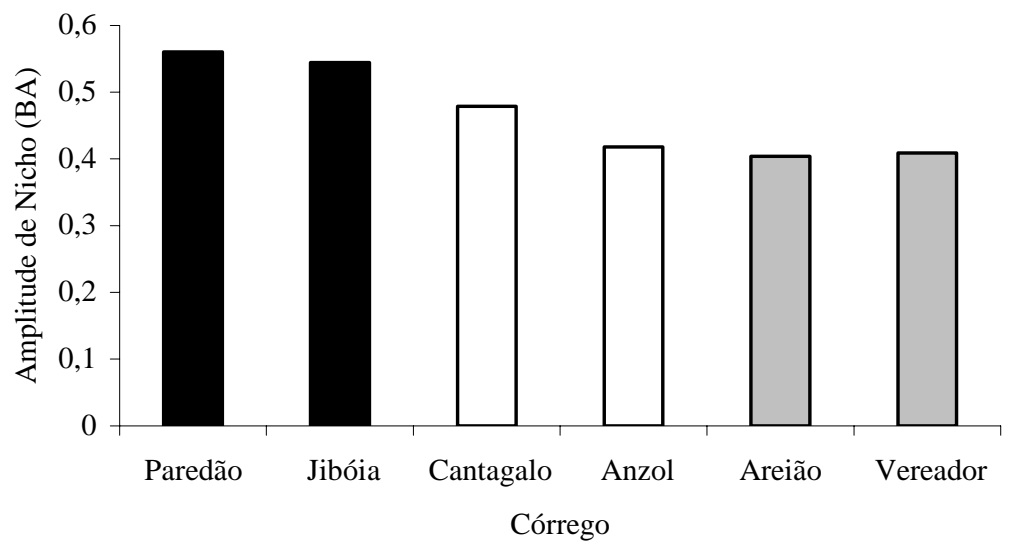

Figura 7 - Amplitude do nicho trófico de Astyanax paranae em seis córregos da bacia do rio Passa-Cinco, SP 
A atividade alimentar de A. paranae durante o período de estudo (período vespertino), mostrou-se elevada para a maioria dos córregos, uma vez que 50\% dos estômagos foram registrados como parcial ou completamente cheios. Apenas no Córrego Paredão a espécie apresentou uma maior quantidade de estômagos vazios ou parcialmente vazios, indicando uma atividade alimentar moderada (Figura 8).

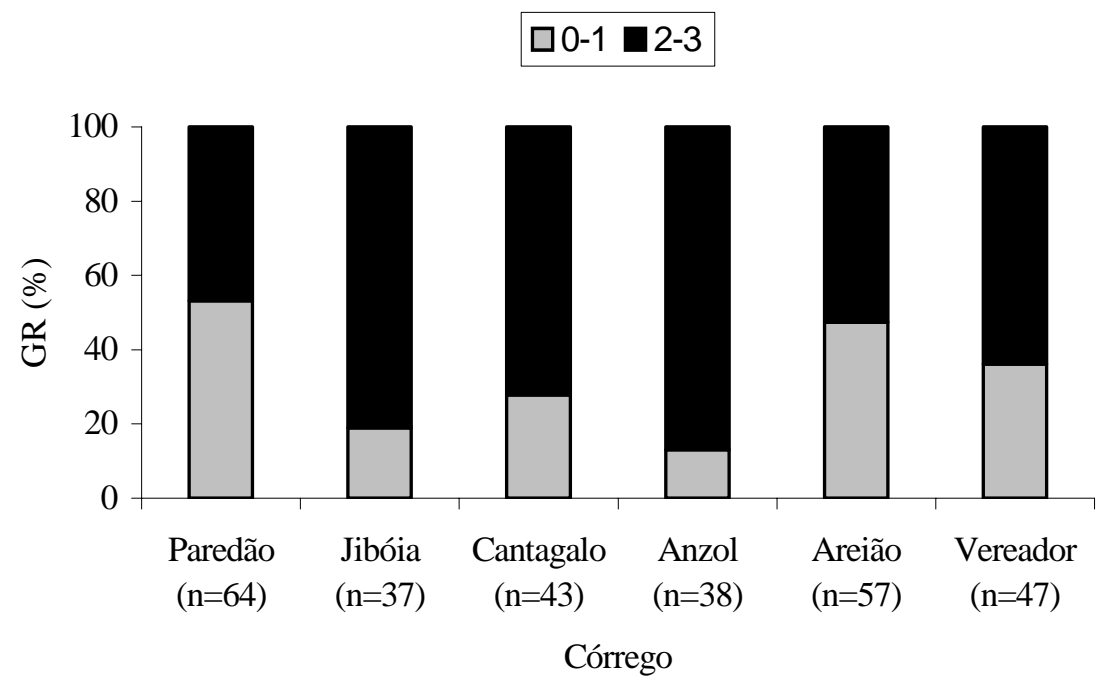

Figura 8 - Atividade alimentar (GR\%) de A. paranae no período vespertino nos córregos da bacia do rio Passa-Cinco, SP

A ordenação espacial com base na dieta de A. paranae (Figura 9) é apresentada através da análise de correspondência. $\mathrm{O}$ eixo 1 foi o mais representativo (autovalor = 0,392) e segregou nos menores escores os córregos Paredão, Areião, Vereador e Anzol, cujos recursos principais foram insetos terrestres, seguidos por vegetais terrestres. Já no Córrego Anzol, apesar do alto consumo do item citado acima e de insetos aquáticos, os peixes apresentaram grande consumo de algas, destacando como o único ponto amostrado onde a espécie consumiu tal alimento (Figura 9A). O eixo 1 ainda permite observar que dos escores intermediários para os maiores, houve a separação dos córregos Cantagalo e Jibóia (Figura 9B). Isto devido ao fato que no Córrego Cantagalo, houve maior quantidade de insetos aquáticos e vegetais terrestres na dieta. Por outro lado, no Córrego Jibóia, os indivíduos exploraram um grande espectro de alimentos, 
onde o volume de Oligochaeta destacou-se perante a alimentação da espécie nos outros locais.
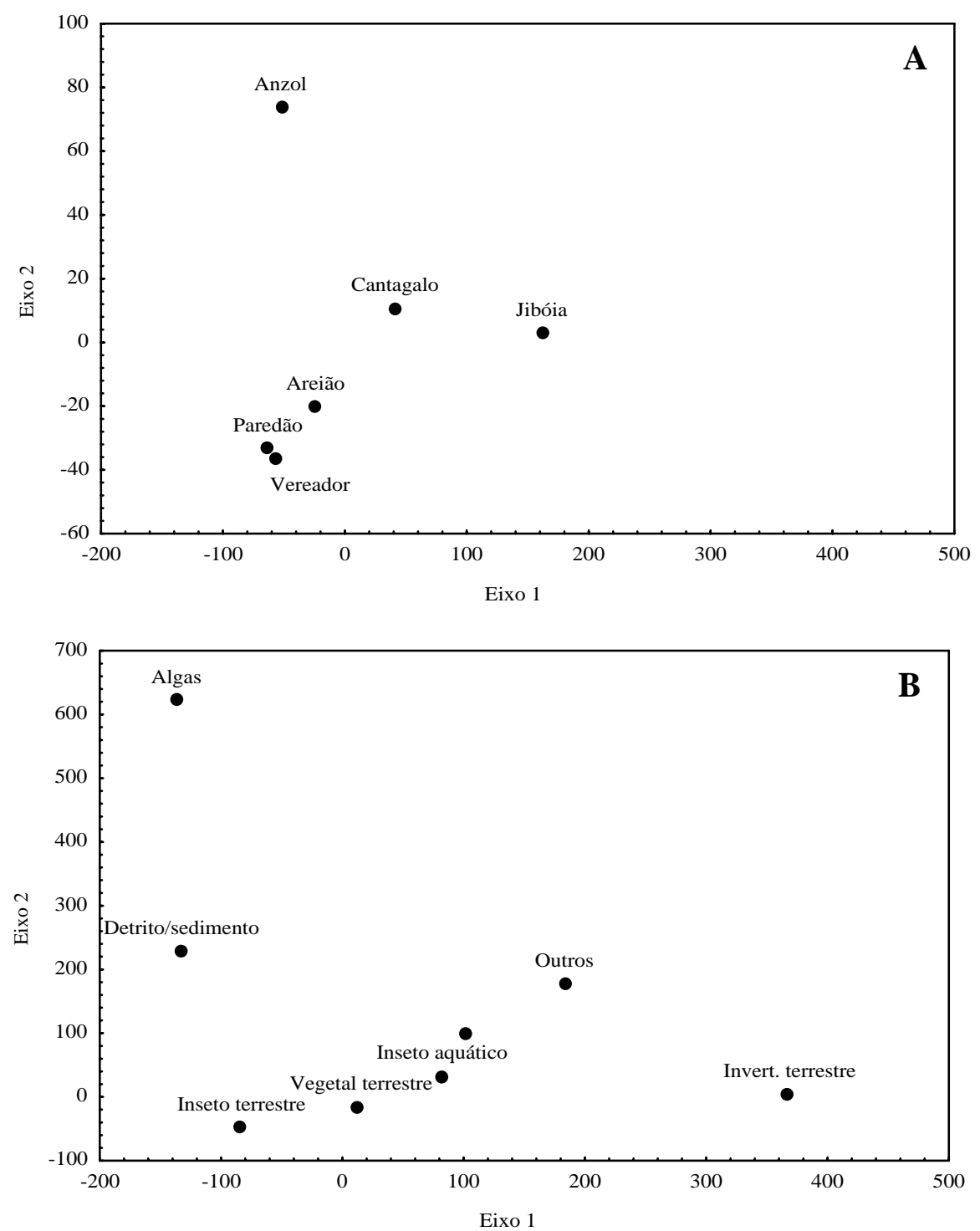

Figura 9 - Ordenação espacial (A) e dos recursos alimentares (B) utilizados por $A$. paranae nos diferentes córregos da bacia do rio Passa-Cinco, SP

O dendrograma construído para demonstrar a similaridade da dieta da espécie entre os locais (Figura 10), apresenta a formação de quatro grupos, demonstrando que, 
apesar da dominância de insetos terrestres na dieta de $A$. paranae na maioria dos córregos, a espécie apresentou um aproveitamento de outras categorias alimentares disponíveis.

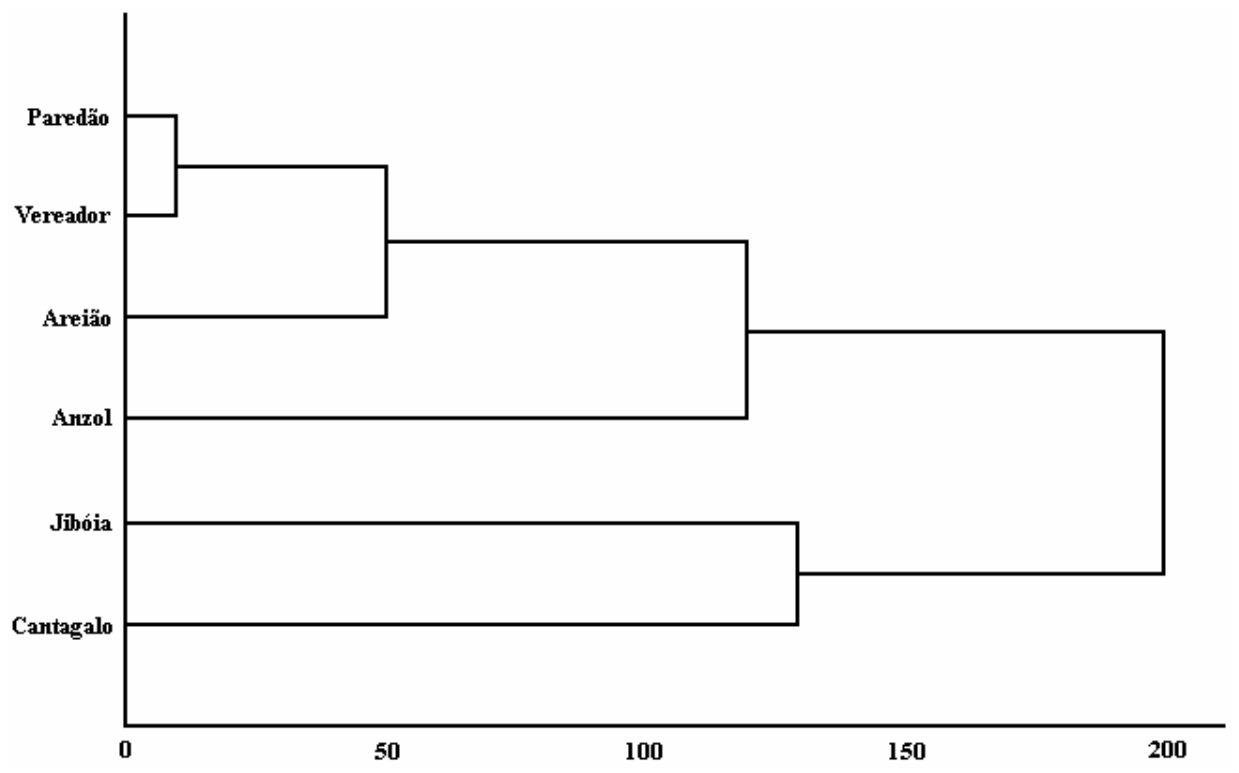

Figura 10 - Dendograma de similaridade entre os córregos e as categorias alimentares utilizadas por A. paranae na bacia do rio Passa-Cinco, SP, obtido através dos escores da DCA

\subsection{Disponibilidade de recursos no ambiente}

Os resultados das amostras de invertebrados na superfície, margens e fundo dos córregos estudados estão nas Tabelas 6 e 7. No geral, a grande maioria é composta por insetos em estágios imaturos e adultos, tanto de origem aquática quanto terrestre. Outros organismos, tais como nematóides, oligoquetos, platelmintos, aracnídeos, microcrustáceos e colêmbolos, também foram encontradas.

Dentre os invertebrados de origem aquática (Tabela 6), Chironomidae e Ephemeroptera, foram os mais abundantes nos córregos Paredão (39,2 e 27,9\%), Jibóia (54,2 e 15,7\%), Cantagalo (54,5 e 36,6\%) e Vereador (55,1 e 21,8\%). No Córrego do Anzol houve uma maior abundância de Chironomidae e, no Córrego Areião, de Ephemeroptera e Chironomidae (41,9 e 29,9\%, respectivamente). 
Os invertebrados de origem terrestre (Tabela 7) apresentaram uma baixa abundância de indivíduos. Colêmbolos e dípteros adultos foram os principais representantes dos invertebrados nos córregos Paredão (28,6 e 19,0\%), Jibóia (16,1 e 31,1\%), Cantagalo (38,1 e 37,7\%), Anzol (31,21 e 33,3\%), Areião (22,4 e 51,4\%) e Vereador (42,3 e 22,7\%) respectivamente. Além destes, sobressaíram as formigas, demais himenópteros e coleópteros adultos, além de ninfas e adultos de hemípteros. 
Tabela 6. Ocorrência (O) e porcentagem de ocorrência (\%) dos invertebrados de origem autóctone nos córregos da bacia do rio Passa-Cinco ( $\mathrm{n}=$ ninfa, 1 = larva, $\mathrm{p}=$ pupa, $\mathrm{a}=$ adulto $)$

\begin{tabular}{|c|c|c|c|c|c|c|c|c|c|c|c|c|}
\hline & \multicolumn{2}{|c|}{ Paredão } & \multicolumn{2}{|c|}{ Jibóia } & \multicolumn{2}{|c|}{ Cantagalo } & \multicolumn{2}{|c|}{ Anzol } & \multicolumn{2}{|c|}{ Areião } & \multicolumn{2}{|c|}{ Vereador } \\
\hline & $\mathrm{O}$ & $\%$ & $\mathrm{O}$ & $\%$ & $\mathrm{O}$ & $\%$ & $\mathrm{O}$ & $\%$ & $\mathrm{O}$ & $\%$ & $\mathrm{O}$ & $\%$ \\
\hline Nematoda & 3 & 0,69 & 9 & 0,97 & 7 & 0,30 & 2 & 0,08 & 2 & 0,28 & & 0,00 \\
\hline Ephemeroptera (n) & 126 & 28,90 & 146 & 15,77 & 865 & 37,09 & 154 & 6,17 & 309 & 42,68 & 30 & 23,26 \\
\hline Odonata (n) & 8 & 1,83 & 69 & 7,45 & 23 & 0,99 & 11 & 0,44 & 58 & 8,01 & 7 & 5,43 \\
\hline Plecoptera (n) & & 0,00 & 32 & 3,46 & 2 & 0,09 & & 0,00 & 2 & 0,28 & 1 & 0,78 \\
\hline Hemiptera $(n+a)$ & 7 & 1,61 & 42 & 4,54 & & 0,00 & 1 & 0,04 & 19 & 2,62 & 10 & 7,75 \\
\hline Coleoptera $(1+a)$ & 54 & 12,39 & 21 & 2,27 & 16 & 0,69 & 2 & 0,08 & 51 & 7,04 & & 0,00 \\
\hline Diptera (l) & 10 & 2,29 & 18 & 1,94 & 14 & 0,60 & 26 & 1,04 & 18 & 2,49 & & 0,00 \\
\hline Chironomidae (l) & 177 & 40,60 & 504 & 54,43 & 1286 & 55,15 & 2205 & 88,34 & 220 & 30,39 & 76 & 58,91 \\
\hline Simuliidae (l) & 4 & 0,92 & 1 & 0,11 & 25 & 1,07 & 44 & 1,76 & 2 & 0,28 & & 0,00 \\
\hline Diptera (p) & 4 & 0,92 & 18 & 1,94 & 18 & 0,77 & 31 & 1,24 & 2 & 0,28 & 2 & 1,55 \\
\hline Simuliidae (p) & 18 & 4,13 & 50 & 5,40 & 4 & 0,17 & 4 & 0,16 & 30 & 4,14 & & 0,00 \\
\hline Trichoptera (l) & 18 & 4,13 & 15 & 1,62 & 68 & 2,92 & & 0,00 & & 0,00 & & 0,00 \\
\hline Lepidoptera (l) & 2 & 0,46 & & 0,00 & & 0,00 & 1 & 0,04 & & 0,00 & & 0,00 \\
\hline Conchostraca & 2 & 0,46 & & 0,00 & & 0,00 & & 0,00 & & 0,00 & & 0,00 \\
\hline Copepoda & 2 & 0,46 & & 0,00 & 4 & 0,17 & 15 & 0,60 & 11 & 1,52 & 2 & 1,55 \\
\hline Hydracarina & 1 & 0,23 & & 0,00 & & 0,00 & & 0,00 & & 0,00 & 1 & 0,78 \\
\hline Turbellaria & & 0,00 & 1 & 0,11 & & 0,00 & & 0,00 & & 0,00 & & 0,00 \\
\hline Total & 436 & 100 & 926 & 100 & 2332 & 100 & 2496 & 100 & 724 & 100 & 129 & 100 \\
\hline
\end{tabular}


Tabela 7. Ocorrência (O) e porcentagem de ocorrência (\%) dos invertebrados de origem alóctone nos córregos da bacia do rio Passa-Cinco ( $\mathrm{n}=$ ninfa, 1 = larva, $\mathrm{p}=$ pupa, $\mathrm{a}=$ adulto)

\begin{tabular}{|c|c|c|c|c|c|c|c|c|c|c|c|c|}
\hline & \multicolumn{2}{|c|}{ Paredão } & \multicolumn{2}{|c|}{ Jibóia } & \multicolumn{2}{|c|}{ Cantagalo } & \multicolumn{2}{|c|}{ Anzol } & \multicolumn{2}{|c|}{ Areião } & \multicolumn{2}{|c|}{ Vereador } \\
\hline & $\mathrm{O}$ & $\%$ & $\mathrm{O}$ & $\%$ & $\mathrm{O}$ & $\%$ & $\mathrm{O}$ & $\%$ & $\mathrm{O}$ & $\%$ & $\mathrm{O}$ & $\%$ \\
\hline Oligochaeta & 2 & 4,76 & & 0,00 & & 0,00 & & 0,00 & & 0,00 & & 0,00 \\
\hline Aranae & 1 & 2,38 & 6 & 3,11 & 2 & 0,77 & 7 & 4,96 & 8 & 3,14 & 7 & 3,21 \\
\hline Collembola & 12 & 28,57 & 31 & 16,06 & 99 & 38,08 & 44 & 31,21 & 108 & 42,35 & 49 & 22,48 \\
\hline Odonata (a) & 2 & 4,76 & 2 & 1,04 & & 0,00 & & 0,00 & & 0,00 & & 0,00 \\
\hline Blattodea (a) & & 0,00 & 1 & 0,52 & & 0,00 & 2 & 1,42 & 1 & 0,39 & & 0,00 \\
\hline Orthoptera (a) & & 0,00 & & 0,00 & & 0,00 & 4 & 2,84 & & 0,00 & 3 & 1,38 \\
\hline Hemiptera $(n+a)$ & 4 & 9,52 & 7 & 3,63 & 15 & 5,77 & 5 & 3,55 & 3 & 1,18 & 13 & 5,96 \\
\hline Coleoptera (a) & 2 & 4,76 & 13 & 6,74 & 3 & 1,15 & 12 & 8,51 & 9 & 3,53 & 2 & 0,92 \\
\hline Diptera (a) & 8 & 19,05 & 60 & 31,09 & 98 & 37,69 & 47 & 33,33 & 58 & 22,75 & 112 & 51,38 \\
\hline Lepidoptera (l) & & 0,00 & & 0,00 & & 0,00 & & 0,00 & & 0,00 & 2 & 0,92 \\
\hline Hymenoptera (a) & 7 & 16,67 & 26 & 13,47 & 27 & 10,38 & 1 & 0,71 & 19 & 7 , & 19 & 8,72 \\
\hline Formicidae (a) & 4 & 9,52 & 44 & 22,80 & 9 & 3,46 & 8 & 5,67 & 25 & 9,80 & 7 & 3,21 \\
\hline Thysanoptera & & 0,00 & 2 & 1,04 & 6 & 2,31 & 4 & 2,84 & 3 & 1,18 & & 0,00 \\
\hline Acari & & 0,00 & 1 & 0,52 & 1 & 0,38 & 7 & 4,96 & 19 & 7,45 & 3 & 1,38 \\
\hline Psocoptera & & 0,00 & & 0,00 & & 0,00 & & 0,00 & 2 & 0,78 & 1 & 0,46 \\
\hline Total & 42 & 100 & 193 & 100 & 260 & 100 & 141 & 100 & 255 & 100 & 218 & 100 \\
\hline
\end{tabular}


Os invertebrados de origem alóctone amostrados neste estudo, tiveram maior diversidade em todos os locais coletados (Figura 11). Houve um maior equilíbrio entre os invertebrados de origem autóctone e alóctone nos córregos Paredão, Jibóia, Areião e Vereador, que são os córregos com cobertura vegetal constituída de mata nativa. No Córrego Cantagalo houve menor diversidade dos organismos em relação aos demais córregos, enquanto que no Córrego do Anzol houve uma maior diferença entre a diversidade de invertebrados terrestres $(0,79)$ e aquáticos $(0,23)$.

\section{Autóctones $\square$ Alóctones}

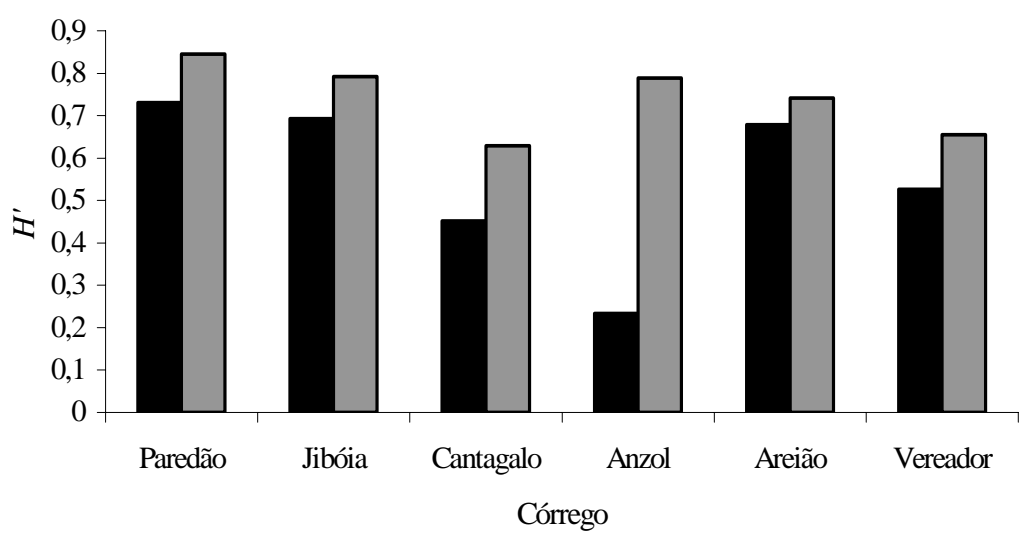

Figura 11 - Diversidade dos invertebrados $\left(H^{\prime}\right)$ de acordo com a origem nos córregos da bacia do rio Passa-Cinco, SP

A análise de eletividade $(E)$ demonstrou que apenas o recurso alóctone foi selecionado positivamente em todos os córregos (valores de $E$ maiores que zero) (Figura 12). Apesar da maior oferta de itens autóctones (selecionados negativamente), a espécie demonstrou preferência pelos itens de origem alóctone. Apenas no Córrego Cantagalo a espécie consumiu itens autóctones na mesma proporção que encontrados no ambiente $(E=-0,05)$. 


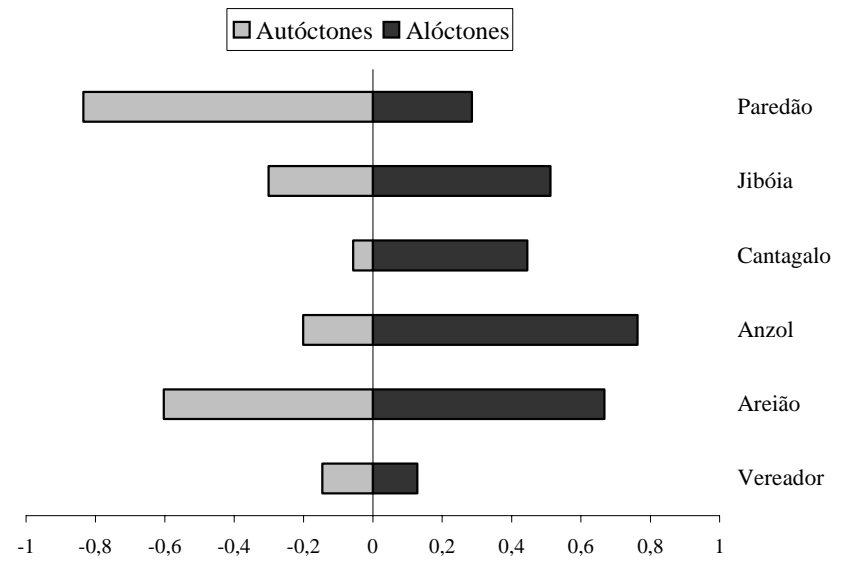

Figura 12 - Índice de Eletividade dos recursos ingeridos por A. paranae em relação aos disponíveis nos córregos amostrados da bacia do rio Passa-Cinco, SP 


\section{DISCUSSÃO}

Apesar da dominância de insetos terrestres na dieta de Astyanax paranae na maioria dos córregos, a espécie demonstrou flexibilidade na dieta ao consumir outros itens alimentares. Agostinho \& Zalewski (1995) e Araújo-Lima et al. (1995) enfatizam que em ambientes aquáticos tropicais, grande parte dos peixes apresentam uma ampla flexibilidade alimentar. Dill (1983) comenta que a flexibilidade alimentar é uma importante característica adaptativa do comportamento alimentar de peixes, uma vez que ambientes naturais variam espacial e temporalmente, e os peixes respondem à baixa disponibilidade alimentar alterando seu comportamento.

Neste estudo, $A$. paranae apresentou um hábito alimentar onívoro com tendência à insetivoria. Lowe-McConnell $(1987$; 1999) define como eurifagia a capacidade das espécies de explorar vários tipos de alimentos, possibilitando uma ampla distribuição das mesmas, permitindo que as espécies onívoras se tornem mais distribuídas do que as especialistas. A dieta dos peixes representa uma integração entre preferências alimentares, disponibilidade e acessibilidade do alimento (Angermeier \& Karr, 1984), assim, os onívoros podem elevar sua probabilidade de sobrevivência, principalmente frente à mudanças ambientais (Gerking, 1994).

Alguns autores estudaram a dieta de A. scabripinnis, como Uieda et al. (1987) em dois trechos do Rio Claro em Minas Gerais, e observaram que a espécie apresenta comportamento insetívoro próximo à nascente, mudando para onívoro mais à jusante. Castro \& Casatti (1997) em um afluente do Rio Pardo (bacia do alto Rio Paraná), também caracterizaram a espécie como onívora com tendência à insetivoria. Vilella et al. (2002) consideraram a espécie onívora no Rio Maquiné (RS) e Roque et al. (2003)

observaram o hábito onívoro-insetívoro e oportunista dessa espécie em um córrego de cerrado em São Carlos (SP). Com relação à alimentação de A. scabripinnis paranae, 
Uieda et al. (1997) a classificaram como insetívora no Córrego Itaúna (SP) e Barbieri (1992) a classificou como onívora a partir do quociente intestinal médio.

O elevado consumo de itens alóctones detectado neste estudo pela espécie demonstra um comportamento de utilização de itens que caem e/ou são arrastados na água, demonstrando a importância da mata ripária na alimentação deste lambari. Sabino \& Castro (1990), num córrego de Mata Atlântica, verificaram que a tática alimentar de Hollandichthys multifasciatus foi a cata na superfície da água (principalmente insetos terrestres), enquanto que Sabino \& Zuanon (1998), em um igarapé amazônico, observaram que Bryconops giacopinni se aproximava da superfície para capturar itens que caíam na água das árvores. Uns dos itens que mais se destacaram na dieta de $A$. paranae em quase todos os pontos de coleta foi Formicidae. Uieda et al. (1987), Castro \& Casatti (1997) e Roque et al. (2003) também encontraram na dieta de A. scabripinnis maior presença de itens de origem alóctone, onde destacaram predomínio no consumo de Formicidae.

No Córrego Cantagalo, a presença de pasto nas margens deve ser um dos fatores que influenciaram na dieta da espécie. Além do consumo maior de insetos aquáticos, outro destaque na dieta foi o consumo elevado de folhas e sementes de gramíneas. Apesar do Córrego do Anzol também possuir pasto em suas margens e um dos principais itens alimentares terem sido as formigas, o peixe apresentou em sua alimentação grandes proporções de insetos aquáticos, além de algas.

A ausência de mata ripária é um dos fatores responsáveis pela proliferação das algas que, de acordo com Luiz et al. (1998), é ocasionada pela falta de sombreamento, permitindo o desenvolvimento principalmente de algas filamentosas em poços e/ou presas à vegetação aquática. O Córrego Cantagalo apresenta maior correnteza e ausência de poço em relação ao Córrego do Anzol, sendo a velocidade da corrente um fator limitante para o desenvolvimento de algas em rios (Margalef, 1983). As algas encontradas nos estômagos do A. paranae no Córrego do Anzol foram principalmente Spirogyra sp. e diatomáceas, as mesmas encontradas por Casatti \& Castro (1998) na dieta de Astyanax rivularis e Bryconamericus sp. num trecho de corredeira no curso superior do Rio São Francisco (MG). A tática alimentar destas espécies é justamente a 
cata de itens arrastados, sendo que os indivíduos permanecem nas margens onde a corrente é menor, e na poda de raízes submersas da vegetação marginal de macrófitas aquáticas ou de algas aderidas sobre as rochas. Segundo a Teoria do Rio Contínuo (Vannote et al.,1980) válida para riachos florestados temperados, as cabeceiras dos rios, que compreendem os córregos de $1^{\mathrm{a}}$ a $3^{\mathrm{a}}$ ordem são fortemente influenciadas pela vegetação ripária, através da reduzida produção autotrófica e elevada entrada de detritos alóctones.

Tanto o Córrego Paredão quanto o Jibóia apresentam melhor estado de conservação da vegetação ripária, com o canal sombreado e um aporte considerável de itens alóctones. $\mathrm{O}$ aporte de recursos terrestres nos cursos d’água, possui grande importância para a alimentação dos peixes, como a entrada de frutos, sementes e insetos terrestres, além do aumento da quantidade de máteria orgânica particulada, importante para alimentação de invertebrados e peixes detritívoros (Vannote et al., 1980; LoweMcConnell, 1999; Esteves \& Aranha, 1999). No Córrego Jibóia, a espécie apresentou consumo de formigas, itens vegetais terrestres e oligoquetas, bem como uma considerável participação de efemerópteros na dieta, determinados provavelmente pela quantidade de matéria vegetal depositado no canal. Segundo Callisto et al. (2001), a grande quantidade de matéria orgânica de origem alóctone nos corpos d’água, favorece a abundância do grupo trófico dos coletores, representado por algumas famílias de efemerópteros, que utilizam a matéria orgânica em suspensão ou acumulada no leito.

A. paranae apresentou uma amplitude do nicho alimentar maior nos córregos Paredão e Jibóia do que nos demais locais, indicando que os indivíduos desta espécie, nestes ambientes, utilizaram mais amplamente os itens alimentares oferecidos, devido também à maior diversidade de recursos e de micro-habitats. A largura de nicho indica o alcance do recurso ou uso do habitat por uma única espécie ao longo de um gradiente ambiental ou dimensional do nicho (Frissell \& Lonzarich, 1996). Nos demais córregos, a espécie apresentou uma dimensão de nicho menor, sendo que as espécies nos córregos, tanto inseridos em pastagem quanto em estado de assoreamento, possuem menor diversidade de micro-habitats a serem explorados. Segundo Frissell \& Lonzarich (1996), uma espécie pode apresentar pequena amplitude de nicho através da dimensão do micro- 
habitat (por exemplo, a mudança na profundidade de um canal), mas uma alta amplitude em outra dimensão, como a cobertura proporcionada por uma floresta, onde há maior oferta de recursos e abrigos.

Tanto o Córrego Areião quanto o Vereador encontram-se em estágios avançados de assoreamento, apresentando leito muito arenoso, a exemplo de muitas microbacias da bacia do rio Passa-Cinco. Estes ambientes são frágeis aos desmatamentos, com fortes tendências à formação de voçorocas, constantes assoreamentos dos cursos d'água e morte da vegetação original (Jacomine, 2001). Este fato foi constatado principalmente no Córrego Areião, onde o canal está totalmente espraiado e com a vegetação ripária perecendo. Apesar de apresentar trechos com mata bem constituída, estes riachos correm em áreas bem degradadas, sendo a provável causa da elevada sedimentação e redução das calhas destes córregos. Isto afeta integralmente a biota, pois destrói os microhabitats presentes nestes ambientes. Algumas espécies são comuns em determinados habitats e micro-habitats e muitas delas apresentam adaptações morfológicas que promovem maior e melhor exploração de um determinado recurso (Silva, 1993).

Nestes riachos assoreados, o comportamento alimentar da espécie demonstrou a importância dos itens alóctones e a capacidade da espécie de explorar os recursos alimentares disponíveis,. principalmente tendo em vista a perda de micro-habitats pelo processo de assoreamento da calha dos riachos e conseqüente diminuição de alimentos autóctones. A maior parte dos indivíduos capturados nestes córregos ocorreu em pequenos poços localizados às margens, onde podiam explorar, além dos itens caídos, os recursos presentes aderidos às raízes suspensas.

Este lambari apresentou uma atividade alimentar intensa, possuindo conteúdo alimentar em grande parte dos estômagos. Segundo Sazima (1980), os lambaris possuem grande mobilidade, deslocando-se amplamente pelos riachos, sendo muito ativos, com comportamento exploratório acentuado. Segundo Casatti (1996), Sabino \& Zuanon (1998) e Casatti et al. (2001), as espécies da subfamília Tetragonopterinae apresentam características típicas de peixes que nadam ativamente na coluna d'água: corpo geralmente alto e comprimido, olhos em posição lateral, nadadeiras peitorais posicionadas lateralmente e nadadeiras dorsais extensas. 
Normalmente, o período de atividade dos Characiformes é diurno (Casatti \& Castro, 1998). Uieda (1984) observou no ribeirão Tabajara (SP) que A. scabripinnis é ativo no período diurno e distribuí-se da meia água à superfície. De acordo com observações subaquáticas realizadas no rio Betari (Iporanga, SP), Astyanax janeiroensis, Deuterodon iguape e Bryconamericus microcephalus apresentavam maior atividade durante o dia (manhã e tarde) e repouso noturno em margens arenosas e calmas, remansos laterais e debaixo da vegetação marginal suspensa (Pedro Gerhard, comunicação pessoal). Como a maioria dos "tetragonopteríneos”, A. paranae se utiliza da visão como estratégia de captura dos alimentos, fato observado nos locais de coleta, onde a espécie se encontrava a meia água, podendo fazer a captura do alimento tanto na superfície quanto catando itens no fundo e arrastados (observações pessoais).

O agrupamento formado pela combinação dos locais de coleta pelos recursos alimentares utilizados confirma os dados discutidos até o momento, separando os córregos onde A. paranae teve um maior aproveitamento de insetos terrestres e com maior cobertura florestal, exceto no Córrego Jibóia, onde a espécie também obteve um maior aproveitamento de outros itens alóctones. A diversidade de recursos se reflete na diversidade da dieta, principalmente nas espécies que possuem maior flexibilidade dos hábitos alimentares (Allan, 1995).

Invertebrados, tanto aquáticos quanto terrestres e principalmente os insetos em diferentes fases de desenvolvimento, são itens constantes na dieta de peixes de água doce (Costa, 1987; Lowe-McConnell, 1987; Garman, 1991; Mattews 1998; Sabino \& Zuanon, 1998 e Russo et al. 2002). Para Mathews (1998), as algas e os invertebrados afetam fortemente a disponibilidade alimentar para os peixes, que combinando suas habilidades de utilização dos habitats, morfologia e hábitos alimentares, ajudam a determinar quais espécies terão êxito na assembléia local.

Nos locais estudados, houve maior incidência da Classe Insecta, que é predominantemente o maior grupo de organismos terrestres, sendo em torno de $10 \%$ das espécies aquáticas (McCafferty, 1981). Os invertebrados aquáticos constituem uma importante comunidade em córregos, rios e lagoas, sendo um dos grandes responsáveis pela conversão da matéria vegetal em tecido animal nos ecossistemas aquáticos, 
participando do fluxo de energia e da ciclagem de nutrientes (McCafferty, 1981; Allan, 1995 e Bueno et al., 2003).

Dentre os invertebrados de origem aquática, as ordens Diptera, representada principalmente pela família Chironomidae, e Ephemeroptera destacaram-se com o maior número de indivíduos em todos os córregos. A família Chironomidae é um grupo ecologicamente importante de insetos (formas imaturas) que ocorre na maioria dos tipos de ecossistemas aquáticos. Freqüentemente ocorrem em alta densidade, diversidade e biomassa, conferindo um significativo valor energético como consumidores e presa (Coffman \& Ferrington Jr., 1996). As formas imaturas de efemerópteros constitui um dos grupos mais comuns e importantes da comunidade de água doce, sendo a maioria detritívoros e/ou herbívoros, apresentando maior diversidade em ambientes com fundo rochoso e ocupando preferencialmente águas correntes (McCafferty, 1981; Edmunds \& Waltz, 1996). Normalmente as fases aquáticas destes insetos constituem os principais itens alimentares de vários peixes (Arcifa et al, 1988; Andrian et al., 1994; Hahn et al. 1997; Hahn et al.,1998).

Uieda \& Gajardo (1996) detectaram que em poções e corredeiras de um córrego em Itatinga (SP), houve um predomínio de indivíduos aquáticos das ordens Diptera, Ephemeroptera, Plecoptera e Coleoptera. Posteriormente, Kikuchi \& Uieda (1998) encontraram no mesmo córrego o predomínio de Calopterygidae (Odonata) e Chironomidae (Diptera). Os quironomídeos também se destacaram como os mais abundantes em dois cursos d’água no Rio Grande do Sul (Bueno et al., 2003).

Neste estudo, os principais representantes dos invertebrados terrestres encontrados caídos e/ou arrastados pelas águas dos diversos córregos, foram os colêmbolos e dípteros (adultos). De acordo com Christiansen \& Snider (1996), os integrantes da Classe Collembola habitam terras, serapilheira e vegetação úmidas, possuindo forte associação com os ambientes aquáticos. Os dípteros adultos são terrestres, embora alguns freqüentem as margens e superfícies dos ambientes aquáticos (McCafferty, 1981).

Uieda \& Kikuchi (1995), estudando dois trechos de um córrego em Itatinga (SP) detectaram o aporte maior no corpo d’água das ordens Diptera, Collembola e 
Hymenoptera. Esses resultados também são semelhantes ao encontrado por Roque et al. (2003) num córrego em São Carlos (SP), onde os grupos mais abundantes foram os adultos de Chironomidae e de outros Diptera, Formicidae e Collembola. Segundo estes autores, a elevada contribuição de Chironomidae, cujas larvas são aquáticas ou semiaquáticas, indica que parte do material exportado para o ambiente terrestre retorna para o ambiente aquático. Neste estudo, não foram identificados os Diptera adultos em nível de família, mas devido à grande abundância de larvas de Chironomidae, pode-se inferir que grande parte dos adultos encontrados sejam desta família.

Houve uma variação na diversidade dos invertebrados encontrados nos córregos estudados no presente trabalho. Apesar da abundância dos invertebrados terrestres com relação aos invertebrados aquáticos ter sido menor, estes apresentaram maior diversidade. Esta menor abundância, provavelmente decorreu de tempo insuficiente de permanência das bandejas de retenção sobre a água. Mesmo assim, o procedimento permitiu ter uma idéia dos organismos que caem nos córregos.

Os córregos Paredão e Jibóia apresentaram maior diversidade entre os invertebrados de origem aquática e terrestre, provavelmente devido à presença de mata ripária. De acordo com Bispo \& Oliveira (1998), os corpos d'água florestados possibilitam maior entrada e acúmulo de fragmentos vegetais, elevando a possibilidade de formação de micro-habitats, o que permite o desenvolvimento de um sistema com vários nichos disponíveis, além de ofertar a queda constante de invertebrados nos corpos d’água. O mesmo foi observado por Callisto et al. (2001) que, em rios da Serra do Cipó (MG), avaliando a diversidade de habitats, caracterizaram a vegetação ripária como um dos substratos de maior riqueza de grupos tróficos funcionais, por ofereceram maior diversidade de micro-habitats.

Nos córregos Areião e Vereador, também houve maior diversidade de invertebrados terrestres, provavelmente devido à presença da vegetação ripária constituída por mata. Grande parte dos invertebrados aquáticos foram encontrados em raízes e vegetação suspensa no canal. A natureza do substrato pode ser um fator limitante na composição da fauna, sendo que substratos rochosos proporcionam maior riqueza e abundância de espécies, enquanto que o substrato arenoso limita a distribuição 
de algumas famílias, devido à escassez de refúgio e disponibilidade de alimento (Allan, 1995; Kikuchi \& Uieda, 1998; Bueno et al.,2003). Segundo Allan (1995) a areia é geralmente considerada um substrato pobre, especialmente para invertebrados devido à sua instabilidade, que não permitindo a retenção de detritos, pode limitar a disponibilidade de oxigênio.

O Córrego Cantagalo apresentou uma maior diversidade de invertebrados aquáticos em relação ao Córrego do Anzol, provavelmente devido à presença do substrato rochoso e de ser formado praticamente por corredeiras. Vários trabalhos indicam que em áreas abertas (sem cobertura florestal) e em corredeiras, ocorre maior abundância de invertebrados aquáticos, devido aos altos níveis de produção primária e algas, disponibilidade de alimentos e presença de refúgios (Angermeier \& Karr, 1984; Uieda \& Gajardo, 1996; Kikuchi \& Uieda, 1998). Mudanças do uso do solo por ações antrópicas afetam a diversidade de invertebrados alterando o número total de táxons, ensejando o aparecimento de uma comunidade distribuída desigualmente, onde um ou dois taxa são dominantes (Death, 2000).

Com relação a utilização dos invertebrados de origem alóctone e autóctone na dieta de A. paranae nos diversos córregos estudados, observou-se que apesar dos locais apresentarem uma maior disponibilidade de invertebrados aquáticos, a espécie preferiu consumir itens alóctones. Provavelmente devido a suas características tanto comportamentais quanto morfológicas, indicando que a dieta desta espécie não reflete simplesmente os itens disponíveis no ambiente. Frente às diferentes características dos córregos, principalmente causadas por ações antrópicas, A. paranae apresentou alguma adaptabilidade trófica. De acordo com Gerking (1994), esta expressão retrata o comportamento alimentar de várias espécies de peixes, que mudam de alimento conforme a necessidade.

Neste trabalho, a dieta de $A$. paranae foi analisada espacialmente, não levando em consideração outros aspectos também importantes como os aspectos sazonais. Segundo Lowe-McConnell (1999) a sazonalidade nos trópicos induz principalmente mudanças no nível da água, alterando qualitativa e quantitativamente a disponibilidade dos alimentos para os peixes. Outro aspecto seria as possíveis variações ontogenéticas na 
dieta e morfológicas. Durante os estágios de desenvolvimento dos peixes, podem ocorrer mudanças na dieta de uma mesma espécie decorrente da demanda energética e das limitações morfológicas durante o crescimento dos indivíduos (Abelha et al., 2001). Em adição, espécies com morfologia, modo de vida e auto ecologia similares, coexistem nos corpos d'água (Frissell \& Lonzarich, 1996) e dependem da disponibilidade alimentar e de processos ecológicos, como predação ou competição, para sobreviveram nestes ambientes (Peres-Neto, 1999). 


\section{CONCLUSÕES}

- As características morfológicas dos córregos e do corredor ripário influenciam na dieta do lambari Astyanax paranae, através da oferta diferenciada dos recursos alimentares;

- Astyanax paranae apresenta um hábito alimentar onívoro com tendência a insetivoria, com maior consumo de itens alóctones;

- O maior consumo de itens alóctones evidencia a importância da vegetação ripária na alimentação desta espécie;

- Os córregos com mata ripária apresentam maior diversidade de invertebrados, tanto terrestres quanto aquáticos, enquanto que os locais com o corredor ripário constituído por pastagem apresentaram maior abundância e menor diversidade;

- A espécie demonstrou capacidade de explorar diversos itens alimentares, no entanto, apesar da disponibilidade de invertebrados aquáticos, houve preferência por itens alóctones (caídos e/ou arrastados), deixando claro que nem sempre o que está disponível será consumido;

- O estado de assoreamento dos córregos não alterou diretamente a dieta da espécie devido a presença de mata ripária nos trechos amostrados, que proporciona maior entrada de recursos alóctones. 
Este trabalho deixa algumas questões sobre a ecologia trófica de A. paranae com relação ao entorno dos riachos:

- Como seria o comportamento alimentar desta espécie ou sua ocorrência, em córregos assoreados, mas sem vegetação ripária constituída por mata nativa?

- As mudanças na composição do corredor ripário poderiam induzir a "competição” intra ou interespecífica por alimento pela ictiofauna?

- Como as características morfológicas influenciam a obtenção dos alimentos?

- Como a espécie faz uso das características morfológicas para se adaptar às novas condições ambientais? 


\section{REFERÊNCIAS BIBLIOGRÁFICAS}

ABELHA, M.C.F.; AGOSTINHO, A.A.; GOULART, E. Plasticidade trófica em peixes de água doce. Acta Scientiarum, v.23, n.2, p.425-434, 2001.

AGOSTINHO, A.A.; ZALEWSKI, M. The dependence of fish community structure and dynamics on foodplain and riparian ecotone zone in Paraná River, Brazil. Hydrobiologia, v.303, p.141-14, 1995.

ALLAN, J.D. Stream ecology. London: Chapman \& Hall, 1995. 388p.

ALVES, A.L.; MARTINS-SANTOS, I.C. Cytogenetics studies in two populations of Astyanax scabripinnis with $2 \mathrm{n}=48$ chromosomes (Teleostei, Characidae). Cytologia Tokyo, v.67, n.2, p.117-122, 2002.

ANDRIAN, I.F.; LANSAC-TÔHA, F.A.; ALVES, L.F. Entomofauna disponível para a alimentação de peixes comedores de superfície em duas lagoas de inundação do alto rio Paraná, Brasil. Revista Unimar, v.16, p.117-126, 1994.

ANGERMEIER, P.L.; KARR, J.R. Fish communities along environmental gradients in a system of tropical streams. In: ZARET, T.M. (Ed.). Evolutinary ecology of neotropical freshwater fishes. Dordrecht: Dr. W. Jung, 1984. p.39-57.

ARAUJO-LIMA, C.R.M.; AGOSTINHO, A.A.; FABRÉ, N.N. Trophic aspects of fish communities in brazilian rivers and reservoir. In: TUNDISI, J.G.; BICUDO, C.E.M.; MATSUMURA-TUNDISI, T. (Ed.). Limnology in Brazil. Rio de Janeiro: ABC;SBL,1995. p.105-136.

ARCIFA, M.S.; FROEHLICH, O.; NORTHCOTE, T.G. Distribution and feeding ecology of fishes in a tropical brazilian reservoir. Sociedad de Ciencias Naturales La Salle, n.8, p.301-326, 1988. 
BARBIERI, G. Dinâmica da nutrição de Astyanax scabripinnis paranae (Characiformes, Characidae) do ribeirão do Fazzari: São Carlos, SP. Revista da Sociedade Brasileira de Zootecnia, v.21, n.1, p.68-72, 1992.

BARBIERI, G. Biologia de Astyanax scabripinnis paranae (Characiformes, Characidae) do ribeirão do Fazzari, São Carlos, Estado de São Paulo.1. Estrutura populacional e crescimento. Revista Brasileira de Biologia, v.52, n.4, p.579-588, 1993a.

BARBIERI, G. Biologia de Astyanax scabripinnis paranae (Characiformes, Characidae) do ribeirão do Fazzari, São Carlos, Estado de São Paulo.2. Aspectos quantitativos da reprodução. Revista Brasileira de Biologia, v.52, n.4, p.589-596, 1993 b.

BICUDO, C.E.M.; BICUDO, R.M.T. Algas de águas continentais brasileiras: chave para identificação de gêneros. São Paulo: Fundação Brasileira para o Desenvolvimento do Ensino de Ciências, 1970. 228p.

BISPO, P.C.; OLIVEIRA, L.G. Distribuição espacial de insetos aquáticos (Ephemeroptera, Plecoptera e Trichoptera) em córregos de cerrado do Parque Ecológico de Goiânia, Estado de Goiás. In: NESSIMIAN, J.L.; CARVALHO, A.L. (Ed.). Ecologia de insetos aquáticos. Rio de Janeiro: Computer \& Publish Editoração, 1998. p.157-173. (Séries Oecologia Brasiliensis).

BORROR, D.J.; DeLONG, D.M. Introdução ao estudo dos insetos. São Paulo: EDUSP, 1969. 635 p.

BRITSKI, H.A. Peixes de água doce do Estado de São Paulo: sistemática. São Paulo: USP, Faculdade de Saúde Pública; Instituto de Pesca, 1972. 216p.

BRITSKI, H.A.; SATO, Y.; ROSA, A.B.S. Manual de identificação de peixes da região de Três Marias: (com chaves de identificação para os peixes da bacia do São Francisco). Brasília: CODEVASF, 1988. 115p.

BRITSKI, H.A.; SILIMON, K.Z.S.; LOPES, B.S. Peixes do Pantanal: manual de identificação. Brasília: EMBRAPA, 1999. 184 p.

BUCK, S.; SAZIMA, I. Na assemblage of mailed catfishes (Loricariidae) in southeastern Brazil: distribution, activity, and feeding. Ichthyological Exploration of Freshwaters, v.6, n.4, p.325-332, 1995. 
BUCKUP, P.A. Sistemática e biogeografia de peixes de riachos. In: CARAMACHI, E. P.; MAZZONI, R.; PERES-NETO, P.R. (Ed.). Ecologia de peixes de riachos. Rio de Janeiro: Computer \& Publish Editoração, 1999. p.91-138. (Série Oecologia Brasiliensis).

BUCKUP, P.A. Astyanax. In: BUCKUP, P.A.; MENEZES, N.A. (Ed.). Catálogo dos peixes marinhos e de água doce do Brasil. 2003. http://www.mnrj.ufrj.br/catalogo/ (22 out. 2003).

BUENO, A. A.P.; BOND-BUCKUP, G.; FERREIRA, B.D.P. Estrutura da comunidade de invertebrados bentônicos em dois cursos d’água do Rio Grande do Sul, Brasil. Revista Brasileira de Zoologia, v.20, n.1, p.115-125, 2003.

CALLISTO, M.; MORENO, P.; BARBOSA, F.A.R. Habitat diversity and benthic functional trophic groups at Serra do Cipó, southeast Brazil. Revista Brasileira de Biologia, v.61, n.2, p.259-266, 2001.

CASATTI, L. Biologia e ecomorfologia dos peixes de um trecho de corredeiras no curso superior do rio São Francisco, São Roque de Minas, MG. Botucatu, 1996. 90p. Dissertação (Mestrado) - Instituto de Biociências, Universidade Estadual Paulista "Júlio de Mesquita Filho".

CASATTI, L. Alimentação dos peixes em um riacho do Parque Estadual Morro do Diabo, bacia do rio Paraná, sudeste do Brasil. Biota Neotropica, v.2, n.2, p.1-14, 2002.

CASATTI, L.; CASTRO, R.M.C. A fish of the São Francisco river headwaters riffles, southeastern Brazil. Ichthyological Exploration of Freshwaters, v.9, n.3, p.229242, 1998.

CASATTI, L.; LANGEANI, F.; CASTRO, R.M.C. Peixes de riacho do parque estadual morro do Diabo, bacia do alto rio Paraná, SP. Biota Neotropica, v.1, n.1, p.1-15, 2001.

CASTRO, R.M.C.; CASATTI, L. The fish fauna small forest stream of the upper Paraná river basin, southeastern Brazil. Ichtyological Exploration Freshwaters, v. 7, n.4, p.337-352, 1997.

CHRISTIANSEN, K.A.; SNIDER, R.J. Aquatic Collembola. In: MERRITT, R.W.; CUMMINS, K.W. (Ed.). Aquatic insects of North America. Oowa: Kendall/Hunt Publ., 1996. p.113-125. 
COFFMAN, W.P.; FERRINGTON JR., L.C. Chironomidae. In: MERRITT, R.W.; CUMMINS, K.W. (Ed.). Aquatic insects of North America. Oowa: Kendall/Hunt Publ., 1996. p.635-754.

CONSELHO NACIONAL DO MEIO AMBIENTE. Resolução CONAMA: $\mathbf{n}^{0}$ 303, de 20 de março de 2002. http://www.mma.gov.br/port/conama. (24 maio 2002).

CORDEIRO, S.N.; GIOIA, I. On a new myxosporean parasite (Myxozoa), Myxidium cholecysticum sp. n., from the freshwater fish Astyanax scabripinnis (Jenyns, 1842). Acta Protozoologica, v.29, n.2, p.157-161, 1990.

COSTA, W.J.E.M. Feeding habits of a fish community in a tropical coastal stream, rio Mato Grosso, Brazil. Studies on Neotropical Fauna and Environment, v.22, p.145153, 1987.

COSTELLO, M.J. Predator feeding strategy and prey importance: a new graphical analysis. Journal of Fish Biology, v.36, p. 261-263, 1990.

DEATH, R.G. The effect of land-use on species-area realtionships in benthic stream invertebrates. Verhandlungen Internationale Vereinigung Limnologie Stuttgart, v.27, p.2519-2522, 2000.

DILL, L.M. Adaptative flexibility in the foraging behavior of fishes. Canadian Journal of Fisheries and Aquatic Sciences,v.40, p.398-408, 1983.

DUFECH, A.P.S.; AZEVEDO, M.A.; FIALHO, C.B. Comparative dietary analysis of two populations of Mimagoniates rheocharis (Characidae: Glandulocaudinae) from two streams of southern Brazil. Neotropical Ichthyology, v.1, n.1, p.67-74, 2003.

EDMUNDS, G.F.; WALTZ, R.D. Ephemeroptera. In: MERRITT, R.W.; CUMMINS, K.W. (Ed.). Aquatic insects of North America. Oowa: Kendall/Hunt Publ., 1996. p.126-163.

ESTEVES, K.E.; ARANHA, J.M.R. Ecologia trófica de peixes de riachos. In: CARAMASHI, E. P.; MAZZONI, R.; PERES-NETO, P.R. (Ed.). Ecologia de peixes de riachos. Rio de Janeiro: Computer \& Publish Editoração, 1999. p. 157-182. (Série Oecologia Brasiliensis). 
ESTEVES, K.E.; LOBÓN-CERVIÁ, J. Composition and trophic structure of a fish community of a clear water Atlantic rainforest stream in southeastern Brazil. Environmental Biology of Fishes, v.62, p.429-440, 2001.

FOWLER, H.W. Os peixes de água doce do Brasil. Arquivos de Zoologia do Estado de São Paulo, v.6, p.1-204, 1948.

FRAGOSO, E.N. Caracterização biológica de Astyanax scabripinnis paranae (Eigenmann, 1914) (Characiformes, Characidade) do córrego da Lagoa, São Carlos, SP. São Carlos, 2000. 195p. Dissertação (Mestrado) - Centro de Ciências Biológicas e da Saúde, Universidade Federal de São Carlos.

FRISSELL, C.A.; LONZARICH, D.G. Habitat use and competition among stream fishes. In: HAUER, F.R.; LAMBERTI, G.A. (Ed.). Methods in stream ecology. San Diego: Academic Press, 1996. p.493-510.

GARMAN, G.C. Use of terrestrial arthropod prey by a stream-dwelling cyprinid fish. Environmental Biology of Fishes, v.30, p.325-331, 1991.

GARUTTI, V.; BRITSKI, H.A. Descrição de uma espécie nova de Astyanax (Teleostei: Characidae) da bacia do alto rio Paraná e considerações sobre as demais espécies do gênero na bacia. Comunicações do Museu de Ciências e Tecnologia da PUCRS Série Zoologia, v.13, p.65-88, 2000.

GERKING, S.D. Feeding ecology of fish. San Diego: Academic Press. 1994. 416p.

GÈRY, J. Characoids of the world. Neptune City: T. F. H. Publ. 1977. 672p.

GIOIA, I.; CORDEIRO, S.N. Henneguya intracornea n. sp. (Myxozoa,: Myxosperea) eye's parasite Astyanax scabripinnis (Jenyns, 1842) (Osteichthyes, Characidae). Memórias do Instuto Oswaldo Cruz, v.81, n.4, p.401-407, 1986.

GIOIA, I.; CORDEIRO, S.N.; ARTIGAS, P.T. Urocleidoides astyanacis n. sp. (Monogenea Ancyrocephalinae) from freshwater characisians of the genus Astyanax. Memórias do Instituto Oswaldo Cruz, v.83, n.1, p.13-15, 1988.

GODOY, M.P. Peixes do Brasil, subordem Characoidei, bacia do rio Mogi Guassu. Piracicaba: Franciscana, 1975. v. 1, 216p. 
GOMES, A.L.; AZEVEDO, P. Os peixes de Monte Alegre do Sul, estado de São Paulo. Papéis Avulsos do Departamento de Zoologia, v.14, n.16, p.133-151, 1960.

HAHN, N.S.; FUGI, R.; ALMEIDA, V.L.L.; RUSSO, M.; LOUREIRO, V.E. Dieta e atividade alimentar de peixes do reservatório de Segredo. In: AGOSTINHO, A.A.; GOMES, L.C. (Ed.). Reservatório de segredo: bases ecológicas para o manejo. Maringá: EDUEM, 1997. p.141-162.

HAHN, N.S.; AGOSTINHO, A.A.; GOMES, L.C.; BINI, L.M. Estrutura trófica da ictiofauna do reservatório de Itaipu (Paraná-Brasil) nos últimos anos de sua formação. Interciência, v.23, n.5, p.299-305, 1998.

HELLAWELL, J.; ABEL, R. A rapid volumetric method for the analysis of the food of fishes. Journal of Fish Biology, v.3, p.29-37, 1971.

HENDERSON, P.A.; WALKER, I. On the leaf litter community of the Amazonian blackwater stream Tarumazinho. Journal of Tropical Ecology, v.2, p.1-17, 1986.

HURBERT, S.H. The measurement of niche overlap and some relatives. Ecology, v.59, p.67-77, 1978.

HYSLOP, E.J. Stomach contents analysis - a review of methods and their applications. Journal of Fish Biology, v.17, p.411-429, 1980.

IVLEV, V.S. Experimental ecology of the feeding of fishes. New Haven: Yale University Press, 1961.

JABLONSKI, E.F.; KOSLOSKI, M.A.; TOLEDO,L. Variabilidade no número de processos rastelares em Astyanax scabripinnis paranae Eigenmann, 1927 (Characiformes, Tetragonopterinae). Estudos de Biologia, v.45, p.5-21, 2000.

JACOMINE, P.K.T. Solos sob matas ciliares. In: RODRIGUES, R.B.; LEITÃO-FILHO, H.F. (Ed.). Matas ciliares: conservação e recuperação. São Paulo: EDUSP, 2001. p.27-31.

JONGMAN, R.H.G.; BRAAK, T.; VAN TONGEREN, O.F.R. Data analysis in community and landscape ecology. Cambridge: Cambridge University Press, 1995. 299p. 
KIKUCHI, R.M.; UIEDA, V.S. Composição da comunidade de invertebrados de um ambiente lótico tropical e sua variação espacial e temporal. In: NESSIMIAN, J.L.; CARVALHO, A.L. (Ed.). Ecologia de insetos aquáticos. Rio de Janeiro: Computer \& Publish Editoração, 1998. p. 157-173. (Séries Oecologia Brasiliensis)

KREBS, C.J. Ecological methodology. Menlo Park: Benjamin/Cummings, 1999. 620p.

KOFFLER, N.F. Uso das terras da bacia do rio Corumbataí em 1990. Geografia, v.18, n.1, p.135-150, 1993.

LANDINI, G.F.; SCHWANTES, A.R.; SCHWANTES, M.L.B. Astyanax scabripinnis (Pisces: Characidae) hemoglobins : structure and function. Brazilian Journal of Biology, v.62, n.4, p.595-599, 2002.

LIMA, F.C.T; MALABARBA, L.R.; BUCKUP, P.A.; SILVA, J.F.P.; VARI, R.P.; HAROLD, A.; BENINE, R.; OYAKAWA, O.T.; PAVANELLI, C.S.; MENEZES, N.A.; LUCENA, C.A.S.; MALABARBA, M.C.S.L.; LUCENA, Z.M.S.; REIS, R.E.; LANGEANI, F.; CASATTI, L.; BERTACO, V.A.; MOREIRA, C.; LUCINDA, P.H.F. Characidae. In: REIS, R.E.; KULLANDER, S.O.; FERRARIS JR., C.J. Check list of the freshwater fishes of South and Central America. Porto Alegre: EDIPUCRS, 2003. p. 104-169.

LOBÓN-CERVIÁ, J.; UTRILLA, C.G.; QUEROL, E.; PUIG, M.A. Population ecology of pike-cichlid, Crenicichla lepidota, in two streams of the Brazilian Pampa subject to a severe drought. Journal of Fish Biology, v.43, p.537-557, 1993.

LOWE-McCONNELL, R.H. Ecological studies in tropical fish communities. Cambridge: Cambridge University Press, 1987. 382p.

LOWE-McCONNELL, R.H. Estudos ecológicos de comunidades de peixes tropicais. São Paulo: EDUSP, 1999. 534p.

LUIZ, E.A.; AGOSTINHO, A.A., GOMES, L.C.; HAHN, N.S. Ecologia trófica de peixes em riachos da bacia do rio Paraná. Revista Brasileira de Biologia, v.58, n.2, p.273-285, 1998.

MAISTRO, E.L.; OLIVEIRA, C.; FORESTI, F. Sympatric occurrence of two cytotypes of Astyanax scabripinnis (Characiformes, Characidae). Genetics and Molecular Biology, v.23, n.2, p.365-369, 2000. 
MAGURRAN, A.E. Ecological diversity and its measurement. Cambridge: Chapman \& Hall, 1988. 179p.

MARGALEF, R. Limnologia. Barcelona: Ediciones Omega, 1983. 101p.

MATTHEWS, W.J. Patterns in freshwater fish ecology. New York: Chapman \& Hall, 1998. 756 p.

McCAFFERTY, W.P. Aquatic entomology. Boston: Jones and Barlett Publ., 1981. 448p.

McCUNE, B.; MEFFORD, M.J. Multivariate analysis of ecological data: version 3.15. Oregon: MjM Software Design, 1995.

MEDRI, M.E.; BIANCHINI, E.; SHIBATTA, O. A.; PIMENTA, J. A. A bacia do rio Tibagi. Londrina: UEL, 2002. 595p.

MENEZES, N.A. Sistemática de peixes. In: AGOSTINHO, A.A.; BENEDITOCECÍLIO, E. Situação atual e perspectivas da ictiologia no Brasil. Maringá: EDUEM, 1992. p. 18-28.

MERRITT, R.W.; CUMMINS, K.W. Aquatic insects of North America. Oowa: Kendall/Hunt Publ., 1996. 862 p.

MIZOGUCHI, S.M.H.N.; MARTINS-SANTOS, I.C. Citogenetic and morphometric differences in populations of Astyanax "scabripinnis" (Pisces, Characidae) from Maringá region, PR, Brazil. Genetics and Molecular Biology, v.21, n.1, p.55-61, 1998.

MOREIRA-FILHO, O.; BERTOLLO, L.A.C. Astyanax scabripinnis (Pisces, Characidae): a species complex. Revista Brasileira de Genética, v.14, n.2, p.331357, 1991.

MORELLI, S.; BERTOLLO, L.A.C.; FORESTI, F.O.; TOLEDO, F.S.A. Cytogenetics considerations on the genus Astyanax (Pisces, Characidae) 1. Karyotipic variability. Caryologia, v.36, n.3, p.235-244, 1983. 
NAKATANI, K.; AGOSTINHO, A.A.; BAUMGARTNER, G.; BIALETZKI, A.; SANCHES, P.V.; MAKRAKIS, M.C.; PAVANELLI, C.S. Ovos e larvas de peixes de água doce: desenvolvimento e manual de identificação. Maringá: EDUEM, 2001. 378p.

NELSON, J.S. Fishes of the world. New York: John Wiley, 1984. 523p.

PERES-NETO, P.R. Alguns métodos e estudos em ecomorfologia de peixes de riachos. In: CARAMASHI, E. P.; MAZZONI, R.; PERES-NETO, P.R. (Ed). Ecologia de peixes de riachos. Rio de Janeiro: Computer \& Publish Editoração Ltda, 1999. p.122. (Série Oecologia Brasiliensis).

PRESCOTT, W.G. Algae of the western great lakes area. Germany: Otto Koeltz Science Publ., 1982. 977 p.

REIS, R.E.; KULLANDER, S.O.; FERRARIS JR., C.J. Check list of the freshwater fishes of South and Central America. Porto Alegre: EDIPUCRS, 2003. 729 p.

ROQUE, F.O.; PEPINELLI, M.; FRAGOSO, E.N.; FERREIRA, W.A.; BARILLARI, P.R.; YOSHINAGA, M.Y.; STRIXINO, S.T.; VERANI, N.F.; LIMA, M.I.S. Ecologia de macroinvertebrados, peixes e vegetação ripária de um córrego de primeira ordem em região de cerrado do Estado de São Paulo (São Carlos, SP). In: HENRY, R. (Ed.). Ecótonos nas interfaces dos ecossistemas aquáticos. São Carlos: Rima Editora. 2003. p.313-338.

RUPPERT, E.E.; BARNES, R.D. Zoologia de invertebrados. São Paulo: ROCA, 1996. 1029p.

RUSSO, M.R.; FERREIRA. A.; DIAS, R.M. Disponibilidade de invertebrados aquáticos para peixes bentófagos de dois riachos da bacia do rio Igraçu, Estado do Paraná, Brasil. Acta Scientiarum, v.24, n.2, p.411-417, 2002.

SÁ, M.F.P. Caracterização de duas populações de Astyanax scabripinnis (Jenyns, 1842) de riachos da bacia do rio São Francisco. São Carlos, 2000. 242p. Tese (Doutorado) Centro de Ciências Biológicas e da Saúde, Universidade Federal de São Carlos.

SABINO, J.; CASTRO, R.M.C. Alimentação, período de atividade e distribuição espacial dos peixes de um riacho da floresta Atlântica (sudeste do Brasil). Revista Brasileira de Biologia, v.50, n.1, p.23-36, 1990. 
SABINO, J.; SAZIMA, I. Association between fruit-eating fish and foraging monkeys in western Brazil. Ichthyological Exploration of Freshwaters, v.10, n.4, p.309-312, 1999.

SABINO, J.; ZUANON, J. A stream fish assemblage in central Amazonia: distribution, activity patterns and feeding behavior. Ichthyological Exploration of Freshwaters, v. 8, n.3, p.201-210, 1998.

SAZIMA, I. Estudo comparativo de algumas espécies de peixes lepidófagos (Osteichthyes). São Paulo, 1980. 264p. Tese (Doutorado) - Instituto de Biociências, Universidade de São Paulo.

SILVA, C.P.D. Alimentação e distribuição espacial de algumas espécies de peixes do igarapé do Candirú, Amazonas, Brasil. Acta Amazonica, v.23, n.2/3, p.271-285, 1993.

SOARES, M.G.M. Aspectos ecológicos (alimentação e reprodução) dos peixes do igarapé do Porto, Aripuanã, MT. Acta Amazonica, v.9, n.2, p.325-352, 1979.

SOARES-PORTO, L.M. Dieta e ciclo diurno de atividade alimentar de Pimelodella lateristriga (Müller e Troschel, 1849) (Siluroidei, Pimelodidae) no rio Ubatiba, Maricá, Rio de Janeiro. Revista Brasileira de Biologia, v. 54, n.3, p.451-458, 1994.

STEHR, F.W. Immature insects. Dubuque: Kendall, 1987. v. 1, 754p.

TAVARES, L.H.S.; BACHION, M.A.; ROCHA, O. Estudo do crescimento populacional de três espécies zoopanctônicas em laboratório e o uso do plâncton na alimentação de alevinos de Oreochromis niloticus (tilápia) e Astyanax scabripinnis paranae (lambari). Revista Unimar, v.16, p.189-201, 1994.

TEIXEIRA, R.L. Aspectos da ecologia de alguns peixes do arroio Bom Jardim, Triunfo - RS. Revista Brasileira de Biologia, v.49, n.1, p.183-192, 1989.

UIEDA, V.S. Ocorrência e distribuição dos peixes em um riacho de água doce. Revista Brasileira de Biologia, v.44, n.2, p. 203-213, 1984.

UIEDA, V.S.; BARRETO, M.G. Composição da ictiofauna de quatro trechos de diferentes ordens do rio Capivara, bacia do Tietê, Botucatu, São Paulo. Revista Brasileira de Zoociências, v.1, n.1, p.55-67, 1999. 
UIEDA, V.S.; GAJARDO, I.C.S.M. Macroinvertebrados perifíticos encontrados em poções e corredeiras de um riacho. Naturalia, v.21, p.31-47, 1996.

UIEDA, V.S.; KIKUCHI, R.M. Entrada de material alóctone (detritos vegetais e invertebrados terrestres) num pequeno curso de água corrente na cuesta de Botucatu, São Paulo. Acta Limnologica Brasiliensia, v. 7, p.105-114, 1995.

UIEDA, V.S.; BUZZATO, P.; KIKUCHI, R.M. Partilha de recursos alimentares em peixes em um riacho de serra do sudeste do Brasil. Anais da Academia Brasileira de Ciências, v.69, n.2, p.243-252, 1997.

UIEDA, V.S.; UIEDA, W.; CARNEIRO, A.B.C.; SILVEIRA. S.A.; MELO, M.L.S.; DORNELAS, R.H. Rede alimentar em duas comunidades de um riacho de água doce. Anais dos Seminários de Ciências da FIUBE, v.1, p.97-113, 1987.

VALENTE, R.O.A. Análise da estrutura da paisagem na bacia do rio Corumbataí, SP. Piracicaba, 2001. 144p. Dissertação (Mestrado) - Escola Superior de Agricultura "Luiz de Queiroz”, Universidade de São Paulo.

VANNOTE, R.L.; MINSHALL, G.W.; CUMMINS, K.W.; SEDELL, J.R.; CUSHING, C.E. The river continuum concept. Canadian Journal of Fisheries and Aquatic Sciences, v.37, p.130-137, 1980.

VEREGUE. A.M.L.; ORSI, M.L. Biologia reprodutiva de Astyanax scabripinnis paranae (Eigenmann) (Ostheichthyes, Characidae), do ribeirão das Marrecas, bacia do rio Tibagi, Paraná. Revista Brasileira de Zoologia, v.20, n.1, p. 97-105, 2003.

VILELLA, F.S.; BECKER, F.G.; HARTZ, S.M. Diet of Astyanax species (Teleostei, Characidae) in an Atlantic Forest river in southern Brazil. Brazilian Archives of Biology and Technology, v.45, n.2, p.223-232, 2002.

WOOTTON, R.J. Constraints in the evolution of fish life histories. Netherlands Journal of Zoology, v.42, p.291-303, 1992. 